\title{
Do national differences in social capital and corporate ethical behaviour perceptions influence the use of collateral? Cross-country evidence
}

\author{
Panagiota Papadimitri ${ }^{1}$, Fotios Pasiouras ${ }^{2 *}$, Menelaos Tasiou ${ }^{1}$ \\ ${ }^{1}$ Portsmouth Business School, University of Portsmouth, UK \\ ${ }^{2}$ Montpellier Business School, France
}

\begin{abstract}
We study the impact of social capital and perceptions about corporate ethical behaviour on the use of collateral in corporate borrowing. Using a dataset of more than 17,500 firms operating in over 100 transition and developing countries, we find evidence that country-level social capital and better perceptions about corporate ethical behaviour are negatively associated with the likelihood to pledge collateral. In addition, these country level characteristics influence the value of collateral relative to the loan value.
\end{abstract}

JEL Codes: G21, G32, G41

Keywords: Social capital, Ethics, Collateral

\footnotetext{
*Author for correspondence. Mail address: Department of Financial Management, Law \& Accounting, ICORE Building, Montpellier Business School, 2300 Avenue des Moulins, 34185 Montpellier Cedex 4, France. Work Phone number: + 33467106 086. E-mails: panagiota.papadimitri@port.ac.uk (Papadimitri $\quad$ P.), $\quad$ f.pasiouras@montpellier-bs.com (Pasiouras F.), menelaos.tasiou@port.ac.uk (Tasiou M.).
}

Acknowledgements: Montpellier Business School (MBS) is a founding member of the public research center Montpellier Research in Management, MRM (EA 4557, Univ. Montpellier). We would like to thank two anonymous referees and Greg Shailer (Section Editor) for valuable comments that helped us improve earlier versions of the manuscript. Any remaining errors are our own. 


\section{Introduction}

Social capital has received a lot of attention in sociology, economics, and management studies (Gao et al., 2019). In recent years, the importance of social capital has also been emphasized in the business ethics literature, with various studies exploring the association between social capital and the use of corporate resources (Gao et al., 2019), fair trade (Davies and Ryals, 2010), responsible entrepreneurship (Fuller and Tian, 2006), the yields of municipal bonds (Li et al., 2018), microfinance performance (Postelnicu and Hermes, 2018), and the quality of financial reports (Jha, 2019). A common underlying idea in these studies is that social capital can enhance trustworthiness and propensity to honour obligations, and constrain unethical behaviour (Li et al., 2018; Gao et al., 2019; Jha, 2019). In this paper, we extend these studies by examining whether and how national differences in social capital and corporate ethical behaviour perceptions influence the use of collateral across countries.

The history of collateral goes back many centuries, having its roots on pawnbroking, a common way of secured lending in ancient Greece, Rome, and the Chinese Buddhist monasteries during the $5^{\text {th }}$ century. Nowadays, collateral is a frequently-used contractual feature in banking, aiming to reduce the risk of lending due to information asymmetry problems. For example, the Survey of Terms of Business Lending conducted by the Board of Governors of the Federal Reserve System in May 2017 (released in August 2017) reveals that $62.4 \%$ of the value of all commercial and industrial loans made by all banks in the U.S., $67.2 \%$ of the value of the corresponding loans made by domestic US banks, and $89 \%$ of the value of the loans made by small domestic banks was secured by collateral. Similarly, data from the latest Enterprise Survey of the World Bank show that $79 \%$ of the loans originated in 139 developing countries required collateral.

Despite the important role of collateral, there has been little empirical research on the determinants of collateralized borrowing in a cross-country context (Nguyen and Qian, 2012), 
with existing studies focusing on country-level characteristics like credit market concentration and macroeconomic conditions (Jiménez et al., 2006), creditor rights and legal origins (Qian and Strahan, 2007; Qi et al., 2011; Yaldiz Hanedar et al., 2014), rule of law, regulatory quality and depth of credit information (Nguyen and Qian, 2012). Therefore, these studies have neglected the role of the social environment, and in particular the social capital and ethical behaviour perceptions. However, these two country level attributes could alleviate concerns about moral hazard, one of the two main reasons for the use of collateral in the context of information asymmetry problems. ${ }^{1}$ For example, as discussed in Hasan et al. (2017a), existing evidence suggests that individuals in societies with higher levels of social capital are less likely to engage in opportunistic, self-serving behaviours. Therefore, banks could perceive social capital as a constraint to opportunistic firm behaviour in debt contracting, lowering their collateral requirements. Similarly, Kim et al. (2014) assert that business ethics may be an important element in contracting bank loans. The main argument is that an ethical borrower does not lie, cheat or steal and behaves honestly. Consequently, ethical borrowers are perceived as less risky and banks will not need to monitor such borrowers intensively to prevent their opportunistic behaviour.

To our knowledge, there are only two studies that provide some preliminary evidence consistent with the above arguments. The first study by Hasan et al. (2017a) finds that banks are less likely to impose a collateral requirement in loans issued to firms headquartered in U.S. counties with higher levels of social capital. However, as their dataset is limited to the U.S., their results are not necessarily generalizable to countries with different institutional development and depth of credit information, and in particular developing countries like those that we examine in the present study. The second study, by Kim et al. (2014) uses a sample

\footnotetext{
${ }^{1}$ Studies that relate the use of collateral with moral hazard are, among others, Boot and Thakor (1994), Boot et al. (1991), Rajan and Winton (1995). The second main reason for the use of collateral is adverse selection, as discussed in, among others, Bester (1985), Chan and Kanatas (1985), and Besanko and Thakor (1987).
} 
from 19 countries to conclude that the ethical behaviour of firms leads to lower loan rates. While they mention that ethical borrowers are required to pledge lower collateral in comparison to non-ethical ones, they use collateral only as a control variable, and their observation is based on descriptive statistics and a $t$-test of mean value differences. Additionally, they focus on the syndicated loan market, where loans are typically extended from large multinational banks to large borrowers in both developed and developing countries. In contrast, the World Bank's Enterprise Survey (WBES) that we use in the present study covers loans from various types of banking and non-banking institutions (microfinance institutions, credit cooperatives) extended not only to large, but also to small and medium enterprises in developing countries.

Our sample includes over 17,500 firms operating in more than 100 developing and transition countries during the period 2003-2017. This ensures a certain degree of heterogeneity, both in the use of collateral and the social environment. While our focus on developing countries is driven by the coverage in WBES, there are at least three reasons that make this an interesting exercise. First, information asymmetry problems can be more severe in developing countries, enhancing the request for collateral (Menkhoff et al., 2012; Yaldiz Hanedar et al., 2014). Second, the use of collateral widely varies among developing countries. ${ }^{2}$ Third, our knowledge on the use of collateral comes mainly from developed markets like the U.S. and Europe, and there is considerably less evidence for developing countries (Menkhoff et al., 2012).

Our results show that country-level social capital and better perceptions about corporate ethics have a negative effect on the likelihood to pledge collateral. Additionally, we find that social capital and ethical behaviour influence the value of the collateral (in relation to the value

\footnotetext{
${ }^{2}$ For instance, according to WBES, the proportion of loans requiring collateral range from $23 \%$ in Brazil to $100 \%$ in Guinea and Sudan. Data from the survey do not correspond to the same year for all countries. For example, the latest data for Brazil are from 2009, the ones for Guinea from 2016, and those for Sudan from 2014. However, the variation in the figures is not due to time differences. For example, in 2013, 28.9\% of the loans in Turkey and $87 \%$ of the loans in Tunisia required collateral.
} 
of the loan). These results are robust to the use of an array of firm and country-specific control variables, sub-samples, and the use of instrumental variable analysis that mitigates concerns regarding reverse causality and confounding effects.

The rest of the paper is structured as follows. Section 2 discusses our hypotheses. Section 3 outlines the data, variables, and methodology. Section 4 discusses the empirical results. Section 5 concludes the study.

\section{Hypotheses development}

\subsection{Social Capital and Collateral}

Collateral is frequently used as a means to mitigate information asymmetry and moral hazard concerns. In our context, such concerns could be associated with opportunistic and self-serving firm actions that have the potential to favour firm shareholders at the expense of the lenders (Hasan et al., 2017a). However, the literature suggests several channels through which social capital can alter the decision-making of individuals that facilitate certain actions and constrain others. This is because people tend to conform to social norms that constrain opportunistic, self-serving behaviour and are associated with either internal (e.g. guilt) or external (e.g. shame and ostracism) sanctions (Elster, 1989; Coleman, 1990; Posner, 2000). Within this context, social networks play an important role in building trust (Coleman, 1988; Putnam, 2000), and theoretical work by Karlan et al. (2009) asserts that network connections between individuals can be used as social collateral to secure informal borrowing. Along the same lines, Knack and Keefer (1997) argue that individuals in higher-trust societies spend less to protect themselves from being exploited in economic transactions, written contracts are less likely to be needed, and they do not have to specify every possible contingency.

Social capital could also facilitate the flow and credibility of information, this being another channel through which it can mitigate moral hazard (Lin and Pursiainen, 2018). For instance, Uzzi (1996) highlights the role of social capital in the credibility of information, 
mentioning that "Social relations make information credible and interpretable, imbuing it with qualities and value beyond what is at hand". (p. 678), as well as that "If trust forms between two actors, a base for fine-grained information transfer is set in place. Such an exchange is unlikely in the absence of trust because information could be used opportunistically" (p. 681).

At this point, it should be mentioned that one may also distinguish between various types of social capital, like bonding social capital, bridging social capital and linking social capital (Woolcock, 2001). Woolcock (2001) mentions that bonding refers to relations between family members, close friends, and neighbours, whereas bridging refers to more distant friends, associates, and colleagues. Bridging can be seen as a horizontal metaphor that implies connections between people who share broadly similar demographic characteristics. Finally, linking is being described as a vertical dimension that has to do with the establishment of alliances with sympathetic individuals in positions of power, and it is associated with the capacity to leverage resources, ideas, and information from formal institutions beyond the community. The Legatum Institute's index of social capital that we use in the empirical part attempts to capture all three dimensions. Therefore, we discuss these types of social capital in more detail along with the Legatum Institute index in the next section. Turning to the empirical literature in finance, in general, the results confirm the effectiveness of social capital in imposing constrains on individuals, like strategic defaults on mortgages (Guiso et al., 2013) and moral hazard in the insurance market (Millo and Pasini, 2010). There is also evidence that firms in high social capital US counties are less prone to engage in corporate tax avoidance (Hasan et al, 2017b), and they obtain better credit terms (Hasan et al., 2017a), as well as that social capital in the country of entrepreneur matters for the campaign performance in the case of crowdfunding (Lin and Pursiainen, 2018). On the basis of the above discussion, we form our first hypothesis as follows: 
Hypothesis 1: The country-level social capital will be negatively associated with the use of collateral.

\subsection{Ethical behaviour and Collateral}

In a discussion on the economics of ethics, Noreen (1988) mentions that while some people are unreservedly opportunistic, others constrain their own behaviour out of an ethical sensibility or conscience. He concludes that "if parties to a transaction believe that the other parties to the transaction are honest and act in good faith, the transaction may be possible where it would not have been possible and dead-weight losses can be avoided" (p. 368). Along the same lines, Weiss (2009) argues that "doing the right thing" matters to firms and their stakeholders, and he discusses various reasons for this. For example, acting legally and ethically may result in savings of billions of dollars each year in lawsuits, settlements and theft. Other costs of unethical behaviour include deterioration of relationships, damage to reputation, and declining employee productivity, creativity and loyalty. In general, as discussed in Bews and Rossouw (2002), ethics can play an important and vital role in facilitating trust. Such trust between the bank and the firm can be an important element in bank-firm relationships (Pasiouras et al., 2019) and access to credit (Moro and Fink, 2013), and it could result in better loan terms, like lower collateral requirements.

Building on past studies, Key and Popkin (1998) also highlight that "Analysis of corporate failures and disasters strongly suggests that incorporating ethics in before-profit decision making can improve strategy development implementation and ultimately maximize corporate profits" (p. 331). Guiso et al. (2015) conclude that the employees' perception for the trustworthiness and ethics of the top managers is positively associated with firm performance, while Kim et al. (2014) concludes that business ethics is an important element in contracting bank loans. Therefore, reflecting upon the above, we state our second hypothesis as follows: 
Hypothesis 2: Firms located in countries with perceptions reflecting a more ethical corporate behaviour are less likely to pledge collateral.

\section{Data, Variables and Methodology}

\subsection{Data}

The firm level data for the present study are obtained from the World Bank's Enterprise Surveys (WBES). ${ }^{3}$ Some firms in the sample are included only once in the Surveys, whereas others may participate more than once. Our final working sample covers an unbalanced panel of over 17,500 firms operating in more than 100 transition and developing countries that obtained a loan over the period 2003 to 2017.

Information on social capital is obtained from the Legatum Institute, whereas information on the perceived ethical behaviour of firms in each country is obtained from the executive opinion survey of the World Economic Forum. Data for the perceived ethical behaviour first became available in 2006, and data for social capital first became available in 2007. Therefore, we had to work under the assumption that these variables do not change over the period 2003-2006 and 2003-2007, respectively. However, the values of these variables do not change much within very short time windows, like from one year to another. ${ }^{4}$ Thus, our approach should not raise important concerns.

\footnotetext{
3 The Enterprise Surveys implemented in European and Central Asian countries are also known as Business Environment and Enterprise Performance Surveys (BEEPS) and are jointly conducted by the World Bank Group, the European Bank for Reconstruction and Development (EBRD), the European Investment Bank (EIB), and the European Commission (EC). Enterprise Surveys in Latin America are jointly funded with the Inter-American Development Bank (IDB). Enterprise Surveys in the Middle East and North Africa are jointly funded with EBRD and the EIB. These Surveys were initiated in 2002 and they cover firm-specific attributes and a broad range of business environment topics. For most countries, an Enterprise Survey is conducted about every 3-4 years. While the surveys were initially conducted by different units within the World Bank, since 2005-06 most data collection efforts have been centralized within the Enterprise Analysis Unit. This resulted in a unified set of core survey questions and a consistent application of survey methodology across countries. Therefore, to ensure consistency the present study uses data from these standardized surveys in the post 2005-2006 period.

4 To give some examples, in the case of SOCIAL the figures are as follows: Ethiopia $=42.19(2007), 42.19$ (2008), 42.19 (2009), 42.37 (2010), 42.37 (2011); Jamaica = 50.33 (2007), 50.33 (2008), 50.33 (2009), 50.33
} 
Data for the control variables are collected from various databases of the World Bank. More precisely, data on the depth of credit information are from the Doing Business project. Information on GDP per capita is from the World Development Indicators database. Countrylevel aggregated banking sector indicators are from the Global Financial Development Database. Information on institutional development is from the Worldwide Governance Indicators project. Information on national culture is from Hofstede Insights. These are detailed further in the following section.

\subsection{Variables}

\subsubsection{Dependent variable}

To construct our dependent variable (COLLATERAL), we rely on the answer to the following question in the WBES: "Referring only to this most recent loan or line of credit, did the financing require collateral?" We assign the value of one to firms that answer yes $($ COLLATERAL $=1)$ and the value of zero otherwise. Therefore, our dummy variable denotes whether firms have pledged collateral to obtain a loan or not.

\subsubsection{Social capital and Corporate Ethical Behaviour}

The social capital index (SOCIAL) that we use is obtained from the Legatum Institute, and it is an aggregate index that is based on three dimensions: (i) Personal and Social Relationships, (ii) Social Norms, and (iii) Civic Participation.

(2010), 50.02 (2011); Chile = 53.94 (2007), 53.63 (2008), 52.24 (2009), 52.52 (2010), 53.52 (2011); Panama = 54.78 (2007), 55.16 (2008), 53.59 (2009), 52.60 (2010), 53.27 (2011). The corresponding figures in the case of ETHICS are as follows: Ethiopia = 3.81 (2007), 3.83 (2008), 3.65 (2009), 3.94 (2010), 3.92 (2011); Jamaica = 3.98 (2007), 3.82 (2008), 3.88 (2009), 3.95 (2010), 3.89 (2011), Chile = 5.46 (2007), 5.34 (2008), 5.47 (2009), 5.56 (2010), 5.54 (2011); Panama = 4.35 (2007), 4.19 (2008), 4.02 (2009), 4.15 (2010), 4.13 (2011). Other countries follow similar patterns. 
The first dimension measures the strength of bonding social capital in the form of personal relationships, family networks and genuine community. The indicators used by Legatum for the estimation of this dimension are based on a survey, and they reflect the perceived level of opportunity to make friends, the ability to count on family/friends for help, the frequency of helping strangers, and the frequency of giving informal financial help. This dimension can influence the use of collateral through various ways. For example, Lee and Persson (2016) highlight that financing from family and friends accounts for the majority of informal finance in both developed and developing countries. This availability of informal financial help can become a tangible asset (money) at request, if needed. In other words, if the entrepreneur is not in position to make a repayment of the loan, family and friends might step in and help with the repayment. This will result in a lower expected default likelihood and better loan terms. Further to this, the willingness of family and friends to provide support will not necessarily be limited to economic resources. As discussed in Cofré-Bravo et al. (2019), these network members can also provide labour and emotional support, they can become a source of experience and support in solving problems, and they can connect the firm with other actors (e.g. export firms, input providers, governmental agencies). Thus, the expectation that members of the firm's network can provide help in various ways is a form of an intangible asset that could result in lower collateral requirements. Finally, the opportunity to make friends and maintain an enhanced network may influence directly or indirectly the formation of a close firm-bank relationship. For example, a social bond between the banker and the borrower can be developed through interpersonal relationships, the exchange of nonprofessional information and the participation in local life (Ferrary, 2003). Additionally, the banker can obtain information indirectly through his or her relationships with members of the network (Ferrary, 2003). These aspects can play an import role in the light of recent evidence indicating that personal relationships between the loan officers and firm executives affect the financial 
constraints of the firms (Anderson et al., 2018), and benefit firms across loan terms (Karolyi, 2018).

The second dimension is a measure of bridging social capital that is manifested in civic norms, social cohesion and engagement. It is based on two survey variables that reflect the trust in institutions, and the level of respect with which people treat each other. This dimension relates to the social capital view arguing that cross-country variations in interpersonal and institutional trust influences perceptions on the likelihood or ability of counter parties in business to act opportunistically (Dowling et al., 2019). For example, Postelnicu et al. (2019) conclude that the risk of losing external social ties increases the willingness to repay loans, suggesting that such ties could serve as a substitute for collateral. Furthermore, high levels of bridging capital facilitate the smooth function of the economy as they represent the level of trust required for institutions and legal systems to prosper (Legatum Institute, 2017). This is particularly important because well-developed formal institutions enhance monitoring, reducing the risk of unfair and opportunistic behaviour in financial transactions, and they can result in lower collateral requirements (Nguyen and Qian, 2012; Dowling et al., 2019). For example, institutional trust may influence owner-manager beliefs for the other party's cooperative behaviour, due to confidence in the institutional mechanisms imposing sanctions and controlling the exchanges (Dowling et al., 2019). Therefore, bridging capital may work as a substitute or complement to formal institutions. As it concerns the level of respect, bridging social capital refers -in general- to weak ties between extra-community networks and heterogeneous groups, and it could result in the provision of various resources like contact points to meet other stakeholders, connection with other networks and organizations, advisory services, source of new ideas, access to information that would otherwise be unavailable or costly to locate etc. (Davidsson and Honig, 2003; Cofré-Bravo et al., 2019). These types of 
relations are often formed on a voluntary basis and require substantial levels of respect and trust between the different parties.

The last dimension is a measure of the linking social capital, reflecting the civic and political participation of a citizenry. To capture this dimension, Legatum uses the following indicators: frequency of donations to charity, the frequency of volunteering, the frequency of voicing opinion to a public official, and voter turnout. Therefore, this dimension also relates to the social altruism index of Knack (1992) that was created from questions about charity, volunteer work, and community involvement in the 1991 National Election Pilot Study and was subsequently found to be positively associated to turnout. In their study of debt contracting in the US, Hasan et al. (2017a) also consider the proportion of eligible voters who actually voted in the construction of a social index. Lee and Persson (2016) also mention that the quality of the (altruistic) relationship serves as "social" collateral. Additionally, Hasan et al. (2017a) highlight several studies which argue that since there are no legal or economic incentives to vote or to take census surveys, data on voter turnout and census response rate capture the ramifications of social norms that emphasize cooperative behaviours (e.g. Guiso et al., 2004, 2010; Funk, 2010; Knack, 2002). The frequency of donations and volunteering also reflect the bonds of trust and reciprocity created in social networks. All these could play an important role in the use of collateral as they foster strong cooperative norms, which in turn limit opportunistic and unethical corporate behaviour (Gao et al., 2019).

To account for the perceived ethical behaviour of firms (ETHICS), we consider the answer to the following question from the Executive Opinion Survey of the World Economic Forum (WEF): "In your country, how do you rate the corporate ethics of companies (Ethical behaviour in interactions with public officials, politicians, and other firms)?" The answer to this question may range from 1 to 7 , with higher figures indicating higher ethical behaviour and vice versa. WEF then aggregates the individual answers to an overall country indicator by 
averaging the responses, acting as a typical evaluation of perceptions about a country's ethical corporate behaviour.

\subsubsection{Control Variables}

MED_SIZE and LARGE_SIZE are dummy variables that control for firm size. MED_SIZE takes the value of one in the case of medium enterprises and the value of zero otherwise. LARGE_SIZE takes the value of one in the case of large enterprises and the value of zero otherwise. Small and micro enterprises form the omitted group captured by the constant. ${ }^{5}$ While the existing literature reveals that size may play a role on the use of collateral, it is inconclusive as for the direction of its impact. This is because smaller firms can be informal, more opaque and less reputable, associated with a higher likelihood of collateralized borrowing. In contrast, small firms may lack adequate collateral, and therefore rely more on reputation and personal relationships as substitutes to collateral (Nguyen and Qian, 2012).

AGE is calculated as the difference between the year of the loan and the year of the firm's establishment, and controls for firm age. The literature suggests that older firms are less likely to have to provide collateral (Nguyen and Qian, 2012; Dias Duarte et al., 2017; Meles et al., 2017).

ISO_CERTIFY is a dummy variable that takes the value of one in the case of firms with an internationally-recognized quality certification (e.g. ISO 9000, ISO 9002), and the value of zero otherwise. The literature suggests that certifications result in lower collateral requirements, possibly due to higher repayment capability (Nguyen and Qian, 2012; Duarte et al., 2017).

\footnotetext{
${ }^{5}$ Micro firms represent only $0.53 \%$ of the firms in the dataset. Therefore, we group them together with small firms and we refer to them as small and micro enterprises.
} 
EXPERIENCE captures the years of working experience of the firm's top manager in the sector. It aims to control for expectations that more experienced managers can achieve higher performance and have good relationships with lending institutions, thereby reducing the need for collateral (Nguyen and Qian, 2012; Dias Duarte et al., 2017).

CRINFO is a country-level index of the depth of credit information, with higher values indicating the availability of more information. Taken from the World Bank Doing Business project, it measures rules and practices affecting the coverage, scope and accessibility of credit information available through either a credit bureau or a credit registry. Therefore, we expect it to be negatively associated with the requirement of collateral (Nguyen and Qian, 2012; Yaldiz Hanedar et al., 2014; Dias Duarte et al., 2017).

GDPCAP is the GDP per capita in a country, serving as a control for country-level overall economic development (Nguyen and Qian, 2012; Yaldiz Hanedar et al., 2014; Dias Duarte et al., 2017).

\subsubsection{Methodology}

Considering the binary nature of the dependent variable, we use a logistic regression model of the following form: ${ }^{6}$

$$
\begin{aligned}
& \operatorname{Pr}\left(\text { Collateral }_{i k t}=1 \mid \text { Social Environment }_{k t}, \text { Firm }_{i k t}, \text { Country }_{k t}, \text { Year }_{t}, \text { Sector }_{i}, \text { Origin }_{k} ; \beta\right) \\
& =\mathrm{F}\left(\beta_{0}+\beta_{1} \text { Social Environment }_{k t}+\beta_{\mathbf{2}}^{\prime} \text { Firm }_{i k t}+\beta_{\mathbf{3}}^{\prime} \text { Country }_{k t}+\beta_{\mathbf{4}}^{\prime} \text { Year }_{t}+\beta_{\mathbf{5}}^{\prime} \text { Sector }_{i}+\beta_{\mathbf{6}}^{\prime} \text { Origin }_{k}\right)
\end{aligned}
$$

Where $\mathrm{F}(\mathrm{x})$ is the sigmoid function $\frac{1}{1+e^{-x}}$, index $i$ denotes firms, $k$ refers to countries and $t$ is the temporal index. 'Collateral' is the dummy variable revealing whether the firm pledged

\footnotetext{
${ }^{6}$ Our approach is consistent with many other studies on the use of collateral that employ Logit/Probit models, like among others, Elsas and Krahnen (2002), Jiménez et al. (2006, 2009), Chakraborty and Hu (2006), Berger et al. (2011), Meles et al. (2017). We also estimate eq. (1) as a linear probability model through the use of OLS, or a fractional response model (to constrain the feasible dependent values to the $[0,1]$ range). The results remain intact and they are available upon request.
} 
collateral or not. 'Social Environment' is the variable of interest and denotes either a country's social capital (SOCIAL) or its perception about ethical corporate behaviour (ETHICS). 'Firm' is a vector of firm-level covariates, and 'Country' is a vector of country-level covariates discussed above. Additionally, all regressions include time ('Year') and industry ('Sector') dummies to capture the temporal and sectoral heterogeneity. Finally, 'Origin' refers to a set of dummy variables for the geographical regions of origin, distinguishing between Sub-Saharan Africa (omitted group dummy captured by the constant), East Asia \& Pacific, Europe \& Central Asia, Latin America \& Caribbean, Middle East \& North Africa, South Asia.

One well-known issue with the use of fixed effects is that time-invariant variables cannot be included in the estimations, and slowly moving variables will usually have high standard errors because they will be highly co-linear with the fixed effects (Beck and Katz, 2001). In our case, as discussed earlier in section 3.1, the two main variables of interest (SOCIAL and ETHICS) are not time-invariant, but they change very slowly over relatively short time periods (e.g. from one year to another) within countries. In other words, they are "sluggish" variables. As discussed in Beck (2001), while one can estimate a specification with fixed effects and sluggish variables, the fixed effects will soak up most of the explanatory power of those slowly changing variables. In other words, as Beck (2001) highlights "Thus, if a variable [...] changes over time, but slowly, the fixed effects will make it hard for such variables to appear either substantively or statistically significant (Beck and Katz, 2001)" (p. 285). Furthermore, the use of fixed effects would imply that our interest lies only on whether the small part of the independent variable that is temporally unstable explains the dependent variable (Beck and Katz, 2001). Therefore, since we cannot introduce country fixed effects into the estimations, we use various country-level control variables and dummies for geographical regions. 


\section{Empirical Results}

\subsection{Main results}

Table 1 presents the correlation coefficients and Table 2 presents descriptive statistics of our baseline model. Overall, it seems that around $73 \%$ of the firms provided collateral to receive bank loans. Around 26\% are large firms, $38 \%$ are medium and $36 \%$ are small. The average firm has been operating for 21 years at the time of requesting a loan, while the average manager had an experience of just over 20 years in her/his career. As far as the variables of interest are concerned, the aggregate index of social capital is on average at 47.70 (out of 100) across the countries and time period in our sample, while the same figure regarding the perception of ethical corporate behaviour stands at 3.82 (out of 7).

[Insert Tables 1 and 2 Around Here]

The estimations of the logit model presented in Table 3 provide support to the two hypotheses stated in Section 2. Columns 1 and 7 correspond to the baseline model described in Section 3.2.4. Seemingly, country-level social capital and better perceptions about corporate ethical behaviour are negatively associated with the likelihood to pledge collateral. To be more informative about the economic significance, Table 3 presents the odds ratios, where a ratio higher (lower) than 1 describes a positive (negative) relationship between variables. Thus, the figures in Column 1 reveal that for every unit increase in SOCIAL the odds of pledging (versus non-pledging) collateral are 0.973 times lower (Column 1), given that the other variables in the model are held constant. Consequently, and to give an example, the odds of pledging collateral for a firm operating in Uruguay in $2016\left(S_{\left.O C I A L_{\text {Uruguay,2016 }}=57.70\right)}\right)$ were 9.4 times lower

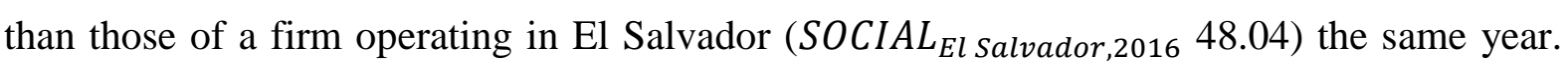
Similarly, with an odds ratio of 0.748 in the case of ETHICS (Column 7), the odds of pledging 
collateral for a firm operating in Tunisia (ETHICS value of 5.06) are 1.03 times lower than the ones of a firm operating in Ecuador (ETHICS value of 3.76). These results complement the findings of Hasan et al. (2017a) who conclude that banks provide loans at a lower interest rate and with less stringent terms to firms headquartered in U.S. counties with higher levels of social capital. Broadly speaking, they also provide support to various studies that go beyond bank lending and support the view that firms from high-social-capital U.S. counties behave less opportunistic either in terms of tax avoidance (Hasan et al., 2017b), or earnings management (Jha, 2019). In a more general context, our findings also provide support to cross-country studies and theoretical work that refer to pressures from the environment, and firm actions to fit within this environment and meet expectations. For example, as discussed in Goodstein (1994), organizations must respond to pressures and demands associated with regulations, norms, laws and social expectations. In our case, it seems that firms that operate in countries with better perfections about corporate ethical behaviour and higher social capital behave in a way that conforms to the expectations of their social peers in the communities and restrain opportunistic behaviour. Bank managers consider this intangible asset and lower their collateral requirements. The latter also relates to the theoretical and empirical work of Karlan et al. (2009), who illustrate the value of network connections as a means of social collateral in the case of informal borrowing in Peru.

[Insert Table 3 Around Here]

In columns (2) to (5) and (8) to (11) we use additional information from the WBES dataset to control for another four firm-specific characteristics. First, following Dias Duarte et al. (2017) and Nguyen and Qian (2012) we control for financial openness (FINOP). This variable may take the value of zero in the case of firms with no checking/savings account or 
overdraft, the value of one in the case of firms that have either checking/savings account or overdraft, and the value of two in the case where a firm has both checking/savings account and an overdraft facility. Second, as in Voordeckers and Steijvers (2006) and Dias Duarte et al. (2017), we control for trade credit (TRCREDIT) using the percentage of the material inputs or services that were paid after delivery. This should provide some information about the creditworthiness of the company, since the suppliers consider the probability of loss due to a buyer's failure to make payments on any type of debt when they provide trade credits to their buyers (Lou and Wang, 2013; Tsao, 2019). Third, we use a dummy variable that indicates whether there are females among the owners of the firm (FEMALE) to account for potential differences in collateral pledging between women-owned firms and men-owned ones (Riding and Swift, 1990; Coleman, 2000). Fourth, we include the ratio of labour cost to annual sales, which reveals the efficiency of labour in generating revenue and serves as an indicator of cost management (LCOST). Columns (6) and (12) of Table 3 present the results when we control simultaneously for all the variables. The inclusion of these four firm-specific attributes in the regressions does not influence our main findings. ${ }^{7}$

In Table 4 we control for banking sector concentration, country-level institutional environment, and national culture. The inclusion of these variables in the regressions does not alter the main findings of Table 3. In the discussion that follows we provide more details about these variables, and the rationale for their inclusion in the regressions.

\footnotetext{
${ }^{7}$ In unreported regressions we include one by one in the baseline regression (Column 1 and 7 of Table 3) another two variables. The first is the ratio of total annual sales to the number of full-time employees that serves as a measure of labour productivity. The second is an indicator that shows whether the sales of main product increase/remain the same/decrease in the last fiscal year. Given that we do not have information on the actual value of sales, we include this indicator either a set of dummy variables to distinguish between the three potential outcomes or as an index that takes the values of -1 (decrease), 0 (no change), 1 (increase). This does not influence the results. In all the cases, the main results hold. We do not include these variables simultaneously with the other firm-level control variables in the regressions because this reduces substantially the sample to 121 observations in the case of SOCIAL and 115 observations in the case of ETHICAL. The estimations are available from the authors upon request.
} 
To control for concentration, we use the proportion of assets held by the three largest commercial banks in a country (CONC). Higher figures indicate that only a few banks dominate in the market, and hence there is a lower degree of competition. The use of CONC is motivated by recent theoretical and empirical work that reveals a negative association between the use of collateral and bank competition (Voordeckers and Steijvers, 2006; Hainz et al., 2013).

As a proxy for institutional environment (INSTIT) we use an overall enforcement index proposed by Li et al. (2006). We calculate INSTIT as the average of the following three indicators from the World Bank's Worldwide Governance Indicators project: regulatory quality, rule of law, control of corruption. Higher figures denote better outcomes. This index aims to control for the likelihood of a better legal and regulatory environment, allowing better contract monitoring and enforcement and hence lower need for collateral (Nguyen and Qian, 2012).

Turning to national culture, we use four dimensions that have been used in past studies that relate to access to finance and risk-taking (Aggarwal and Goodell, 2014, Li et al., 2013; Kreiser et al., 2010; Mihet, 2012). These are: an index of individualism (INDIV), an uncertainty avoidance index (UAI), an index of masculinity (MASC), and a power distance index (PDI).

INDIV reveals the extent to which people's self-image in the society is defined in terms of "I" or "we." This national culture dimension could influence the request for collateral in various ways. On the one hand, individualism has been associated with overconfidence (Chui et al., 2010; Ferris et al., 2013) that could lead, for example, to more efficient research and development and a higher number of patents (Shao et al., 2013; Chen et al., 2017). Under this 
scenario, due to the intrinsic firm value originating from overconfidence, individualism could be negatively associated to the likelihood of collateral use. On the other hand, managerial overconfidence can lead to corporate investment distortions (Malmendier and Tate, 2005), and firms led by overconfident CEOs may be less responsive to corrective feedback in improving management forecast accuracy (Chen et al., 2015). Further to this, the literature also suggests that individualism is positively related to corporate risk-taking (Mihet, 2012; Li et al., 2013), and mortgage default rate (Tajaddini and Gholipour, 2017). Under this scenario, we would expect individualism to lead to higher collateral requirements, due to either higher risk-taking or firm value distortions. UAI is defined as "the extent to which a culture programs its members to feel either uncomfortable or comfortable in unstructured situations" (Hofstede 2001, p.19). Aggarwal and Goodell (2014) conclude that uncertainty avoidance has a negative impact on access to finance, while Hofstede et al. (2010) point out that when it comes to financial matters, people from high uncertainty avoidance countries have more worries about money and they take fewer risks. The literature shows that this applies to firms also, documenting that firms take lower risks in countries with a higher uncertainty avoidance culture (Kreiser et al., 2010; Li et al., 2013; Gaganis et al., 2019). Therefore, we control for this cultural dimension under the assumption that, in countries characterized by higher uncertainty avoidance, firms will not take excessive risks, and lenders will feel (on average) more confident that their loans are secured without the need for collateral.

According to Hofstede et al. (2010) "a society is called masculine when emotional gender roles are clearly distinct: men are supposed to be assertive, tough, and focused on material success, whereas women are supposed to be more modest, tender, and concerned with the quality of life" (p. 140). As a result, organizations in masculine societies stress results and try to reward achievement according to performance (Hofstede et al., 2010). Both Kreiser et al. (2010) and Mihet (2012) argue that this could encourage higher managerial risk-taking 
behaviour. Therefore, we would expect that higher masculinity in a society is associated with higher requirements for collateral. However, the empirical results of the aforementioned studies do not provide strong support to the masculinity risk-taking relationship. In more detail, while Mihet (2012) finds some evidence to support this argument, this is not robust across all the specifications. Furthermore, Kresier et al. (2010) and Li et al. (2013) find no evidence of statistically significant association between masculinity and risk-taking. In contrast, others report that a culture of masculinity results in corporations with larger cash and other liquid balances (Chang and Noorbakhsh, 2009), and lower debt (Wang and Esqueda, 2014). As both higher liquidity and lower leverage would be perceived as positive signals from the perspective of banks, these findings point to a negative association between a culture of masculinity and collateral requirements.

PDI reveals "the extent to which the less powerful members of institutions and organizations within a country expect and that power is distributed unequally" (Hofstede et al., 2010, p.61). At the organizational level, a culture of power distance is associated with unlimited power for managers over their subordinates, autocratical decisions made by a few at the top, vertical communication, employees that expect decisions and instructions from their superiors (Ghosh, 2011). The literature provides conflicting results as for the impact of PDI on risk-taking. On the one hand, Kreiser et al. (2010) outline that: (i) managers in low power distance cultures will be much more willing to follow risky offensive strategies, while managers in high power distance ones will be more likely to adopt "fortify-and-defend" strategies that solidify their current position in the industry; (ii) organizations in power distance cultures tend to maintain tight control mechanisms and implement hierarchical bureaucratic structures. Their empirical results show that power distance is negatively associated with firm risk-taking, a finding that is confirmed by Mihet (2012). Under this scenario we would expect PDI it to be negatively associated with collateral requirements. However, others point to a 
positive association between power and risk, that could translate in higher collateral requirements. For example, Anderson and Galinsky (2006) refer to the Approach/Inhibition Theory and propose that possessing power increases people's risk appetite. In more detail, they argue that: (i) powerful people with a more active behavioral approach system should attend more to reward-laden information, and therefore when given the choice to engage in a risky course of action they should focus more on the potential payoffs of that risk; (ii) powerful people with a less active behavioral inhibition system should attend less the potential dangers inherent in that risk. Overall, it seems that focusing on rewards and being less aware of dangers should drive powerful people towards higher risk-taking. Díez-Esteban et al. (2019) show that this extends to national culture as well, reporting that firms in countries with high scores of power distance tend to increase risk taking.

\section{[Insert Table 4 Around Here]}

Columns (1) and (2) in Table 5 present further estimations of the baseline specification by excluding the years of the crisis from the analysis. Even though inclusion of year dummies in our baseline specification controls for average temporal effects, excluding the years of the crisis (2007-2010) in particular ensures that the results are not driven by that turbulent period during which the requirements for collateral might be higher. Restricting the sample in this way does not influence the results, with the odds ratios being qualitatively similar to the ones

presented in Table 3. Columns (3) to (8) present separate regressions for small and micro, medium and large firms (Yaldiz Hanedar et al., 2014), allowing us to examine if the impact of 
SOCIAL and ETHICS on collateral varies by size. ${ }^{8}$ We find that SOCIAL and ETHICS continue to have a negative impact on the likelihood to pledge collateral regardless of firm size.

The analysis presented in earlier estimations includes loans granted from private banks, state owned/government agencies and non-bank financial institutions. Nonetheless, collateral requirements might vary across different types of credit institutions (Nguyen and Qian, 2012). Therefore, in columns (9) and (10) we present the estimations while restricting our sample to loans from private banks, representing approximately $85.4 \%$ of the sample. Our key findings hold.

[Insert Table 5 Around Here]

\subsection{Collateral value}

As a further exercise, we turn our attention to the value of the collateral expressed as a percentage of the loan value (COLVAL). Information for COLVAL is obtained from the answer to the following question in the WBES: "Referring only to this most recent line of credit or loan what was the approximate value of the collateral required as a percentage of the loan value?". Given that the dependent variable is truncated at zero (left-censored), we estimate a Tobit model, following Elsas and Krahnen (2002) and Yaldiz Hanedar et al. (2014). The results are presented in Table 6 . We consider all firms regardless of whether they pledge collateral or not. In particular, for firms that do not pledge collateral, COLVAL takes the value of zero. Complementing the previous results about the likelihood to pledge collateral, we now find that both SOCIAL and ETHICS lower the value of collateral asked to be pledged by firms. In

\footnotetext{
${ }^{8}$ The regressions presented earlier control for size; however, the inclusion of size as a control variable does not allow us to examine whether the coefficients of the variables of interest (i.e. SOCIAL, ETHICS) vary by firm size.
} 
unreported regressions, we confirm that these results hold even with the use of OLS instead of a Tobit model.

\section{[Insert Table 6 Around Here]}

\subsection{Endogeneity}

One may argue that the results presented so far are clouded by endogeneity. Reverse causality should not be a concern in our context since it is difficult to argue that the collateralrelated policies of individual banks and firms influence a country's social capital or perceptions of corporate ethical behaviour. However, one could still claim that endogeneity is present due to omitted variable bias. Therefore, while having controlled for various firm and country-level characteristics (including national culture, formal institutions, and geographical regions), we turn to instrumental variables regressions as a more formal way to address endogeneity concerns. Within this context, due to the binary and non-linear nature of our regression model (equation 1), we rely on a Two-Stage Residual Inclusion (2SRI) regression system (Terza et al., 2008). In the first stage, our endogenous variable (SOCIAL or ETHICS in equation 1) is regressed on our instruments and exogenous variables of equation (1). Subsequently, in the second stage, we use the residuals of the first stage as an additional regressor in equation (1). We resort on three instruments that we expect to correlate with the first stage dependent variables, but not with the second stage error term. In the discussion that follows, we briefly outline the relationship between these instruments and the two variables of interest (i.e. SOCIAL and ETHICS). ${ }^{9}$

\footnotetext{
${ }^{9}$ In unreported regressions we use two alternative instruments commonly employed in the literature. The first is religion, captured by the percentages of a country's populations being Catholics, Muslims, and Protestants, those being the three most widely spread religions in the world in 1980s. The second is colonization, captured by dummy variables that distinguish between British colonies, Latin colonies, and colonies of others (e.g. China, Turkey, Germany). The results hold and all the estimations are available from the authors upon request.
} 
The first instrument that we use is the ancestry adjusted predicted genetic diversity, estimated on the basis of migratory distance from East Africa in the study of Ashraf and Galor (2013). The underlying idea is that during human evolution there must have been many transitional patterns of behaviour (Lasker and Crews, 1996). For example, Baker et al. (2006) summarize the following lines of research that provide evidence for a genetic basis of antisocial behaviour: (i) behavioural genetic studies of twins and adoptees have demonstrated that heredity plays a role in antisocial behaviour, including various forms of aggression and criminality, (ii) various aspects of antisocial behaviour, including personality factors like impulsivity, sensation-seeking, risk-taking, and callous-unemotional traits, are at least partly genetically driven, (iii) psychiatric outcomes show that antisocial behaviour, including personality disorder, gambling, and substance use and abuse, is influenced by genetics. Further to this, behavioural genetics studies show that measures of behaviour, depression, anxiety and personality are typically 30-50\% heritable (Bouchard and Loehlin, 2001; Polderman et al., 2015). Turning to cooperative behaviour, the results of Cesarini (2008) suggest that human genetic variation influences the decision to invest and to reciprocate investment in the classic trust game. Additionally, Wootton et al. (2016) report broad sense heritability estimates of 57\% for generalized trust and 51\% for trust in friends. Finally, recent cross-country empirical studies document that genetic diversity in the population is related to lower level of interpersonal trust (Arbatli et al., 2019) and corruption (Kunieda et al., 2016). To sum up, it seems that parents transmit behavioural patterns together with genes to their offspring, making genetic diversity a suitable instrument for social capital and ethical behaviour.

The second instrument that we use is latitude, measured as the (absolute) value of the latitudinal distance from equator. Following Hall and Jones (1996), among others, we use this as a rough indicator of climate. Geographic latitude has been used for instance as an instrument of social capital in the studies of Folland (2007), Lee and Law (2017), Xiong et al. (2017). As 
discussed in Xiong et al. (2017), citizens in high latitude areas are in general forced to trust each other to survive harsh weather. In contrast trade has in general been more developed in coastal regions (low latitude) and citizens may be more open-minded towards strangers. Gupta and Hanges (2004) also mention that physical climate in a region can influence the goals of people living in that region, and they highlight that the physical climate hypothesis has been nearly as popular for explaining societal behaviours as the competing hypotheses of religion and history-shaped institutions. As an example, they refer to Huntington (1915) and Montesquieu (1748/1989). The first supported the so-called climate hypothesis, arguing that most of the variance in social and economic behaviours can be explained in terms of the differences in physical climates. Along the same lines, the second articulated how physical climate shapes various sociocultural behaviour, including work ethic.

The third instrument that we use is the agricultural potential, measured by the mean potential caloric yield attainable given the set of crops that were suitable for cultivation in the post-1500 period (Galor and Ozak, 2016). Meggers (1954) argues that in places that are unfit for agriculture, subsistence derived from hunting, fishing and gathering will normally support only small groups that must be constantly on the move. As a result, social organization is largely based on kinship lines, with the social unit being a single family or, at best, an extended family or lineage. Hofstede et al. (2010) mention that farmers had to collaborate in monotonous, season-bound work, and they lived in much greater numbers than huntergatherers or herders. This required a certain meekness, possibly related to higher social cooperation. Along the same lines, Ashkanasy et al. (2004) refer to the work of Ouchi (1981), mentioning that due to low suitability for agriculture in Japan, the planning and harvesting of rice can only be achieved with the cooperation of twenty or more people. Therefore, the Japanese had to learn to work together in harmony, and this explains the societal value that individual considerations are outweighed by concerns for group welfare. On top of that, 
Hofstede et al. (2010) mention that the possession of storable food that could pass from one person to another in agricultural societies led to inheritance. Also, it led to unethical behaviour in the form of large-scale theft, that became an important concern, possibly for the first time in human history. To avoid widespread theft, there should be trust within the groups, followed by heavy sanctions against offenders (Hofstede et al., 2010). Finally, Gaganis et al. (2019) also use agricultural potential as an instrument for trust, while Litina (2016) empirically documents that lower level of land productivity in the past is associated with higher levels of current social capital, measured by generalized trust.

The re-estimation of the baseline specifications in Table 3 (Columns 1 and 7) with the instrumental approach of Terza et al. (2008) are given in Table 7, providing support to our main finding, i.e. that there exists a casual effect of SOCIAL and ETHICS on the use of collateral. Apparently, our approach cannot rule out all endogeneity concerns; however, it should lessen major concerns. Let us note here that the 2SRI specification is just a variant of Davidson and MacKinnon's (1993) suggestion of an augmented regression test (often known as Durbin-Wu-Hausman test), according to which a statistically significant coefficient for the residuals of the auxiliary regression included in the second stage means that the estimators of the variables of interest are not consistent on their own, thus suggesting endogeneity. This is confirmed as residuals of both variables of interest (i.e. $\varepsilon_{\text {SOCIAL }}$ and $\varepsilon_{\text {ETHICS }}$ ) appear to be statistically significant. Moreover, aside from the conceptual justification of the instruments given in this section, statistical justification is also present, with all instruments being statistically significant and the significance of the first -auxiliary- stage overall model validated (F-statistic). It should be mentioned at this point that, because of the non-linear setting of eq. (1), we cannot obtain diagnostics such as under, weak or over-identification tests. Regardless, if we estimate the model using a Two-Stage Least Squares setting -thereby treating our baseline model as a linear probability one-, diagnostics for under (Kleibergen-Paap rk LM statistic), 
weak (Kleibergen-Paap rk Wald F statistic) and over-identification (Hansen J) pass the recommended thresholds for both variables of interest ${ }^{10}$. The results in Table 7 remain the same for all the specifications estimated in earlier sections (i.e. further controls and sub-samples). ${ }^{11}$

[Insert Table 7 Around Here]

\section{Conclusions}

This study aims to extend our knowledge on the driving factors of collateral in corporate borrowing. Within this context, we use a sample of over 17,500 firms from more than 100 developing countries to investigate the role of a country's social capital and perceptions on corporate ethical behaviour on collateral requirements.

The empirical results are consistent with our expectations. We find that country-level social capital and better perceptions on corporate ethical behaviour are negatively associated with the likelihood to pledge collateral. Further analysis reveals that these country-level characteristics influence not only the likelihood to pledge collateral, but also its value relative to the loan value. These results hold while controlling for various firm-specific and countryspecific characteristics, as well as when we use instrumental analysis to mitigate endogeneity concerns.

This study has various implications. The most important is that the ethical behaviour of firms can have beneficial outcomes in the form of lower collateral requirements during borrowing. This is of great value for firm managers and owners since the absence of collateral restricts firm entry and post-entry growth, an issue that is amplified in the case of SMEs, young firms and in transition countries (Schmalz et al., 2017; Abraham and Schmukler, 2017; Love

\footnotetext{
${ }^{10}$ It is worth mentioning that although the 2SLS approach disregards the binary nature of the dependent variable, it remains an option which is viable and less complex, as pointed out by Angrist and Pischke (2008).

${ }^{11}$ To conserve space, we do not report all the specifications. All the results are available from the authors upon request.
} 
et al., 2016; Moreno-Badia and Slootmaekers 2009). These results have possibly implications that go beyond collateral requirements, extending to the bank-firm relationships in general. However, as discussed in Bews and Rossouw (2002), "trust is not simply a given, but something that can be earned by managers" (p. 385). Therefore, firms should invest on an ethical behaviour that will result in trustworthiness and will benefit their bank-firm relationships. For example, Bews and Rossouw (2002), propose various ethical interventions that can make a significant contribution in promoting ethics and trust like the adoption of an ethical code, trusttraining, procedural transparency, etc. The adoption of such ethical related policies is undoubtedly necessary, but it may not play a role as an intangible asset, unless it is appropriately communicated. The main purpose of this communication should be to strengthen the connection between the firm and its stakeholders, including of course its bank and the wider social community. This brings us to our second contribution that relates to an emerging strand of the literature that documents the role of social environment on economic behaviour. In a sense, we document that banks perceive social capital and perceptions about corporate ethical behaviour as environmental pressures that constrain opportunistic behaviour in corporate borrowing. Within this context, our study has also policy making implications. While it is difficult to impose regulations that have to do with deep-rooted social norms, policy makers could take steps to encourage the fostering of cooperative norms, social networks, and trustworthiness. Additionally, they could consider the role of the social environment, when designing collateral laws or introducing collateral registries.

Our study has at least two weaknesses. First, the anonymity of firms in the database of the World Bank's Enterprise Survey does not allow us to collect additional firm-level information and match it with our dataset. Second, our analysis focuses on transition and developing countries covered in the WBES. Thus, it is not possible to examine if the results differ across different levels of institutional and economic development. We hope that, as more 
or different datasets will become available, future research will effectively deal with these issues. Future research could also be directed towards at least two more avenues. For example, the Legatum index of social capital that we use is an overall indicator aiming to capture all three types of social capital, namely bonding, bridging, linking. However, there are no subindices for each of these dimensions. Subject to data availability future research could examine if the impact of social capital on collateral differs among the three types. Additionally, the corporate ethical behaviour perceptions and social capital that we use in the present study are at the country-level. Future research could collect firm level data, that would also allow one to examine how these attributes interact with other firm-level characteristics. At the same time, the acquisition of detailed firm-level data could also help in answering additional questions. For example, how should firms manage their investment in social capital, and to what extent does responsible behaviour create competitive advantages and power when negotiating with their lenders? Conducting such an investigation at a cross-country setting constitutes a largescale exercise that requires substantial resources, and it was not possible to pursue in this analysis. We hope that future research will improve upon this.

\section{References}

Abraham F., Schmukler S. L., (2017), Addressing the SME finance problem, World Bank Research \& policy briefs, No. 9, Washington, D.C: World Bank Group.

Acemoglu D., Johnson S., Robinson J., (2001), The Colonial Origin of Comparative Development: An Empirical Investigation, American Economic Review, 91, 1369-1401.

Aggarwal R., Goodell J.W., (2014), Cross-national differences in access to finance: Influence of culture and institutional environments, Research in International Business and Finance, 31, 193-211.

Alexander M., (2007), Determinants of Social Capital: New Evidence on Religion, Diversity and Structural Change, British Journal of Political Science, 37, 368-377.

Anderson C, Galinsky A.D., (2006), Power, optimism, and risk-taking, Europeran Journal of Social Psychology, 36, 511-536.

Anderson G., Bahaj S., Chavaz M., Foulis A., Pinter G., (2018), Lending relationships and the collateral channel, Staff Working Paper No 768, November, Bank of England.

Angrist, J. D., Pischke, J.S., (2010), The credibility revolution in empirical economics: How better research design is taking the con out of econometrics, Journal of Economic Perspectives, 24, 3-30. 
Arbatli C.E., Ashraf Q.H., Galor O., Klemp M., (2019), Diversity and Conflict, Econometrica, In Press.

Ashkanasy N., Gupta V., Mayfield M.S., Trevor - Roberts E., (2004), Future Orientation, In: House R.J., Hanges P.J., Javidan M., Dorfman P.W., Gupta V. (Eds), Culture, Leadership and Organizations: The Globe Study of 62 Societies, SAGE Publications Inc., pp. $282-$ 342.

Ashraf Q., Galor O., (2013), The 'Out of Africa' Hypothesis, Human Genetic Diversity, and Comparative Economic Development, American Economic Review, 103, 1-46.

Baker L.A., Bezdjian S., Raine A., (2006), Behavioral Genetics: The Science of Antisocial Behavior, Law and Contemporary Problems, 69, 7-46.

Beck N., (2001), Time-Series-Cross-Section Data: What Have We Learned in the Past Few Years? Annual Revie of Political Science, 4, 271-293.

Beck N., Katz J.N., (2001), Throwing out the Baby with the Bath Water: A Comment on Green, Kim, and Yoon, International Organization, 55, 487-495.

Berger A.N., Espinosa-Vega M.A., Frame W.S., Miller N.H., (2011), Why do borrowers pledge collateral? New empirical evidence on the role of asymmetric information, Journal of Financial Intermediation, 20, 55-70.

Besanko D., Thakor A.V., (1987), Collateral and rationing: sorting equilibria in monopolistic and competitive credit markets, International Economic Review, 28, 671-689.

Bester H., (1985), Screening vs. rationing in credit markets with imperfect information, American Economic Review, 75, 850-855.

Bews NF., Rossouw G.J., (2002), A Role for Business Ethics in Facilitating Trustworthiness, Journal of Business Ethics, 39, 377 - 390.

Boot A., Thakor A.V., (1994), Moral hazard and secured lending in an infinitely repeated credit market game, International Economic Review, 35, 899-920.

Boot, A.W.A., Thakor, A.V., Udell, G.F., (1991), Secured lending and default risk: equilibrium analysis, policy implications and empirical results, Economic Journal, 101, 458-472.

Cabolis C., (2018), Corruption and ethical practices perceptions, IMD World Competitiveness Center, Criterion of the Month, August.

Cai Y., Kim Y., Li S., Pan C., (2019), Tone at the top: CEOs' religious beliefs and earnings management, Journal of Banking and Finance, 106, 195-213.

Cesarini D., Dawes C.T., Fowler J.H., Johannesson M., Lichtenstein P., Wallace B., (2008), Heritability of coopertive behavior in the trust game. Proceedings of the National Academy of Sciences, 105, 3721-3726

Chakraborty A., Hu C.X., (2006) Lending relationships in line-of-credit and non-line of- credit loans: evidence from collateral use in small business, Journal of Financial Intermediation, 15, 86-107.

Chan Y., Kanatas G., (1985), Asymmetric valuations and the role of collateral in loan agreements. Journal of Money, Credit and Banking, 17, 84-95.

Chang K., Noorbakhsh A., (2009), Does national culture affect international corporate cash holdings? Journal of Multinational Financial Management, 19, 323-342.

Chen G., Crossland C., Luo S., (2015), Making the same mistake all over again: CEO overconfidence and corporate resistance to corrective feedback, Strategic Management Journal, 36, 1513-1535.

Chen Y, Podolski E.J., Veeraraghavan M., (2017), National culture and corporate innovation, Pacific-Basin Finance Journal, 43, 173-187.

Chui A.C.W., Titman S., Wei K.C.J., (2010), Individualism and Momentum around the World, Journal of Finance, 65, 361-392. 
Cofré-Bravo G., Klerkx L., Engler A., (2019), Combinations of bonding, bridging, and linking social capital for farm innovation: How farmers configure different support networks, Journal of Rural Studies, 69, 53-64.

Coleman J., (1988), Social Capital in the Creation of Human Capital, American Journal of Sociology, 94, S95-S120.

Coleman J.S., (1990), Foundations of social theory, Harvard University Press, Cambridge, MA.

Davidson R., MacKinnon J.G., (1993), Estimation and Inference in Econometrics, Oxford University Press, New York.

Davidsson P., Honig B., (2003), The role of social and human capital among nascent entrepreneurs, Journal of Business Venturing, 18, 301 - 331.

Davies I.A., Ryals L.J., (2010), The Role of Social Capital in the Success of Fair Trade, Journal of Business Ethics, 96, 317-338.

Dias Duart F., Matias Gama A.P., Esperanca J.P., (2017), Collateral - based in SME lending: The role of business collateral and personal collateral in less-developed countries, Research in International Business and Finance, 39, 406-422.

Díez-Esteban J.M., Farinha J.B., García-Gómez C.D., (2019), Are religion and culture relevant for corporate risk-taking? International evidence, BRQ Business Research Quarterly, $22,36-55$.

Du X., (2015), Does Confucianism Reduce Minority Shareholder Expropriation? Evidence from China, Journal of Business Ethics, 132, 661-716.

Dowling M., O’Gorman C., Puncheva P., Vanwalleghem D., (2019), Trust and SME attitudes towards equity financing across Europe, Journal of World Business, In press

Du X., Jian W., Zeng Q., Du Y., (2014), Corporate Environmental Responsibility in Polluting Industries: Does Religion Matter? Journal of Business Ethics, 124, 485-507.

Elsas R., Krahnen J.P., (2002), Collateral, Relationship Lending and Financial Distress: An Empirical Study on Financial Contracting, Center for Financial Studies (CFS) Working Paper No. 2002/17.

Elster, J., (1989), Social Norms and Economic Theory, Journal of Economic Perspectives, 3, 99-117.

Fagerland, M. W. (2014). adjcatlogit, ccrlogit, and ucrlogit: Fitting ordinal logistic regression models. Stata Journal, 14(4), 947-964.

Ferrary M., (2003), Trust and social capital in the regulation of lending activities, Journal of Socio-Economics, 31, $673-699$.

Ferris S.P., Jayaraman N., Sabherwal S., (2013), CEO Overconfidence and International Merger and Acquisition Activity, Journal of Financial and Quantitative Analysis, 48, 137-164.

Folland S., (2007), Does “community social capital" contribute to population health? Social Science \& Medicine, 64, 2342-2354.

Fuller T., Tian Y., (2006), Social and Symbolic Capital and Responsible Entrepreneurship: An Empirical Investigation of SME Narratives, Journal of Business Ethics, 67, 287-304.

Funk P., (2010), Social Incentives and Voter Turnout: Evidence from the Swiss Mail Ballot System, Journal of the European Economic Association, 8, 1077-1103.

Furbey R., Dinham A., Farnell R., Finneron D., Wilkinson G., Howarth C., Hussain D., Palmer S., (2006), Faith as social capital. Connecting or dividing? The Policy Press.

Gaganis C., Hasan I., Pasiouras F., (2019), National Culture and Housing Credit, Mimeo.

Gaganis, C., Hasan, I., Papadimitri, P., Tasiou, M., (2019), National culture and risk-taking:

Evidence from the insurance industry, Journal of Business Research, 97, 104-116.

Galor O., Ozak O., (2016). The agricultural origins of time preference. American Economic Review, 106, 3064-3103. 
Gao Z., Li L., Lu L.Y., (2019), Social Capital and Managers' Use of Corporate Resources, Journal of Business Ethics, In press.

Gelfand M.J., Bhawuk D.P.S., Nishi L.H., Bechtold D.J., (2004), Individualism and collectivism, In: House R.J., Hanges P.J., Javidan M., Dorfman P.W., Gupta V., (Editors), Culture, Leadership and Organizations: The Globe Study of 62 Societies, Sage Publications, pp. 437-512.

Goodstein J.D., (1994), Institutional Pressures and Strategic Responsiveness: Employer Involvement in Work-Family Issues, The Academy of Management Journal, 37, 350382.

Guiso L., Sapienza P., Zingales L., (2006), Does Culture Affect Economic Outcomes? Journal of Economic Perspectives, 20, 23-48.

Guiso L., Sapienza P., Zingales L., (2013), The Determinants of Attitudes toward Strategic Default on Mortgages, Journal of Finance, 68, 1473 - 1515.

Guiso L., Sapienza P., Zingales L., (2015), The Value of Corporate Culture, Journal of Financial Economics, 117, 60-76.

Guiso, L., Sapienza P., Zingales L., (2004), The Role of Social Capital in Financial Development, American Economic Review, 94, 526-556.

Guiso, L., Sapienza P., Zingales L., (2009), Cultural Biases in Economic Exchange? Quarterly Journal of Economics, 124, 1095-1131.

Guiso, L., Sapienza P., Zingales L., (2010), Civic Capital as the Missing Link, In: Benhabib J., Bisin A., Jackson M. (Eds), Handbook of Social Economics, Oxford, UK: Elsevier Science, pp. 417-480.

Gupta V., Hanges P.J., (2004), Regional and Climate Clustering of Societal Cultures, In: House R.J., Hanges P.J., Javidan M., Dorfman P.W., Gupta V. (Eds), Culture, Leadership and Organizations: The Globe Study of 62 Societies, SAGE Publications Inc., pp. $178-$ 218.

Hainz C., Weill L., Godlewski C.J., (2013), Bank Competition and Collateral: Theory and Evidence, Journal of Financial Services Research, 44, 131-148.

Hasan I., Hoi C.K., Wu Q., Zhang H., (2017a), Social Capital and Debt Contracting: Evidence from Bank Loans and Public Bonds, Journal of Financial and Quantitative Analysis, 52, 1017-1047.

Hasan I., Hoi C-K., Wu Q., Zhang H., (2017b), Does Social Capital Matter in Corporate Decisions? Evidence from Corporate Tax Avoidance, Journal of Accounting Research, $55,629-668$.

Hofstede G., (2001), Culture's Consequences: Comparing Values, Behaviors, Institutions and Organizations across Nations, Thousand Oaks, CA: Sage.

Hofstede, G., Hofstede G.J., Minkov M., 2010. Cultures and organizations: Software of the Mind, (Rev. 3rd ed.). McGraw-Hill: New York.

Huntington E., (1915), Civilization and climate, Yale University Press, New Haven.

Jha A., (2019), Financial Reports and Social Capital, Journal of Business Ethics, 155, 567596.

Jiménez G., Salas V., Saurina J., (2006), Determinants of Collateral, Journal of Financial Economics, 81, 252- 281.

Jiménez G., Salas V., Saurina J., (2009), Organizational distance and use of collateral for business loans, Journal of Banking and Finance, 33, 234-243.

Jin Y., Shi H., Zhang X., (2019), Religious social norms and CSR deficiency disclosure, AsiaPacific Journal of Accounting \& Economics, 26, 409-433.

Jordan J.B. (2015), A Study in How Linking Social Capital Functions in Community Development, PhD Dissertation, The University of Southern Mississippi. 
Karlan D., Mobius M., Rosenblat T., Szeidl A., (2009), Trust and Social Collateral, Quarterly Journal of Economics, 124, 1307-1361.

Karolyi S.A., (2018), Personal Lending Relationships, Journal of Finance, 73, 5-49.

Key S., Popkin S.J., (1998), Integrating ethics into the strategic management process: doing well by doing good, Management Decision, 36, 331-338.

Kim M., Surroca J., Tribo J.A., (2014), Impact of ethical behavior on syndicated loan rates, Journal of Banking and Finance, 38, 122-144.

Knack S., (2002), Social Capital and the Quality of Government: Evidence from the States, American Journal of Political Science, 46, 772-785.

Knack S., Keefer P., (1997), Does Social Capital Have an Economic Payoff? A Cross-Country Investigation, Quarterly Journal of Economics, 112, 1251-1288.

Kreiser P.M., Marino L.D., Dickson P., Weaver K.M., (2010), Cultural Influences on Entrepreneurial Orientation: The Impact of National Culture on Risk Taking and Proactiveness in SMEs, Entrepreneurship Theory and Practice, 34, 959-984.

Kunieda T., Okada K., Shibata A., (2016), Corruption, Financial Development and Economic Growth: Theory and Evidence From an Instrumental Variable Approach With Human Genetic Diversity, Economic Notes by Banca Monte dei Paschi di Siena SpA, 45, 353392.

La Porta R., Lopez-de-Silanes F., Shleifer A., Vishny R., (1999), The quality of government, Journal of Law, Economics, and Organization, 15, 222-279.

Lasker G.W., Crews D.E., (1996), Behavioral Influences on the Evolution of Human Genetic Diversity, Molecular Phylogenetics and Evolution, 5, 232-240.

Lee S., Persson P., (2016), Financing from Family and Friends, Review of Financial Studies, $29,2341-2386$.

Lee W.C., Law S.H., (2017) Roles of Formal Institutions and Social Capital in Innovation Activities: A Cross-Country Analysis, Global Economic Review, 46, 203-231.

Legatum Institute, (2017), Social capital and prosperity, 29 November, Available at: https://www.prosperity.com/feed/Social-capital-and-prosperity

Li D., Moshirian F., Pham P.K., Zein J., (2006), When Financial Institutions Are Large Shareholders: The Role of Macro Corporate Governance Environments, Journal of Finance, 61, 2975-3007.

Li K., Griffin D., Yue H., Zhao L., (2013), How does culture influence corporate risk-taking, Journal of Corporate Finance, 23, 1-22.

Li P., Tang L., Jaggi B., (2018), Social Capital and the Municipal Bond Market, Journal of Business Ethics, 153, 479-501.

Licht A., Goldschmidt C., Schwartz S., (2005), Culture, Law, and Corporate Governance, International Review of Law and Economics, 25, 229-255.

Licht A., Goldschmidt C., Schwartz S., (2007), Culture Rules: The Foundation of the Rule of Law and Other Norms of Governance, Journal of Comparative Economics, 35, 659688.

Lin T-C., Pursiaine V., (2018), Fund What You Trust? Social Capital and Moral Hazard in Crowdfunding, Available at SSRN: http://dx.doi.org/10.2139/ssrn.3088905

Litina A., 2016. Natural land productivity, cooperation and comparative development. Journal of Economic Growth, 21, 351-408.

Lou K-R., (2013), Optimal trade credit and order quantity when trade credit impacts on both demand rate and default risk, Journal of the Operational Research Society, 64, 1551 1556.

Love I., Martinez Peria M.S., Singh S., (2016), Collateral Registries for Movable Assets: Does Their Introduction Spur Firms' Access to Bank Financing? Journal of Financial Services Research, 49, 1-37. 
Malmendier U., Tate G., (2005), CEO Overconfidence and Corporate Investment, Journal of Finance, 60, 2661-2700.

Meles A., Porzio C., Sampagnaro G., Starita M.G., VerdolivaV., (2017), Collateralization of business loans: Testing the prediction of theories, Research in International Business and Finance, 42, 922-938.

Menkhoff L., Neuberger D., Rungruxsirivorn O., (2012), Collateral and its substitutes in emerging markets' lending, Journal of Banking and Finance, 36, 817-834.

Mihet R., (2012), Effects of Culture on Firm Risk-Taking: A Cross-Country and Cross Industry Analysis, IMF Working Paper 12/210.

Milo G., Pasini G., (2010), Does social capital reduce moral hazard? A network model for nonlife insurance demand, Fiscal Studies 31, 341-372.

Montesquieu C., (1989), The spirit of laws, Cohler A.M., Miller B.C., Stone H.S., (Translation), Cambridge University Press, New York (Original work published 1748).

Moreno-Badia M., Slootmaekers V., (2009), The Missing Link Between Financial Constraints and Productivity, IMF Working Paper 09/72, April.

Moro A., Fink M., (2013), Loan managers' trust and credit access to SMEs, Journal of Banking and Finance, 37, 927-936.

Nash R., Patel A., (2019), Instrumental Variables Analysis and the Role of National Culture in Corporate Finance, Financial Management, In press

Nguyen H., Qian R., (2012), The Cross-Country Magnitude and Determinants of Collateral Borrowing, World Bank Policy Research Working Paper 6001.

Noreen E., (1988), The economics of ethics: a new perspective on agency theory, Accounting, Organizations \& Society, 13, 359-369.

Pasiouras F., Bouri E., Roubaud D., Galariotis E., (2019), Culture and multiple firm-bank relationships: a matter of secrecy and trust? Mimeo.

Pitta D.A., Fung H-G., Isberg S., (1999), Ethical issues across cultures: managing the differing perspectives of China and the USA, Journal of Consumer Marketing, 16, 240256.

Posner, E. (2000), Law and Social Norms, Harvard University Press, Cambridge, MA.

Postelnicu L., Hermes N., (2018), Microfinance Performance and Social Capital: A CrossCountry Analysis, 153, 427-445.

Postelnicu L., Hermes N., Servin R., (2019), External Social Ties and Loan Repayment of Group Lending Members: A Case Study of Pro Mujer Mexico, The Journal of Development Studies, 55, 1784-1798.

Qi Y., Roth L., Wad J.K., (2011), How legal environments affect the use of bond covenants, Journal of International Business Studies, 42, 235-262.

Qian J., Strahan P.E., (2007), How Laws and Institutions Shape Financial Contracts: The Case of Bank Loans, Journal of Finance, 62, 2803-2834.

Rajan R., Winton A., (1995), Covenants and collateral as incentives to monitor, Journal of Finance, 50, 1113-1146.

Riding A.L., Swift C.S., (1990), Women Business Owners and Terms of Credit: Some Empirical Findings of the Canadian Experience, Journal of Business Venturing, 5, 327340.

Schmalz M.C., Sraer D.A., Thesmar D., (2017), Housing Collateral and Entrepreneurship, Journal of Finance, 72, 99-132.

Serra D., (2006), Empirical determinants of corruption: A sensitivity analysis, Public Choice, 126, 225-256.

Shao L., Kwok C.C.Y., Zhang R., (2013), National culture and corporate investment, Journal of International Business Studies, 44, 745-763. 
Tajaddini R., Glolipour H.F., (2017), National Culture and Default on Mortgages, International Review of Finance, 17, 107-133

Terza J.V., Basu A., Rathouz P. J., (2008), Two-stage residual inclusion estimation: addressing endogeneity in health econometric modeling, Journal of health economics, 27, 531-543.

Tsao Y-S., (2019), Coordinating contracts under default risk control-based trade credit, International Journal of Production Economics, 212, 168-175.

Uzzi B., (1996), The Sources and Consequences of Embeddedness for the Economic Performance of Organizations: The Network Effect, American Sociological Review, 61, 674-698.

Voordeckers W., Steijvers T., (2006), Business collateral and personal commitments in SME lending, Journal of Banking and Finance, 30, 3067-3086.

Weiss J.W., (2009), Business Ethics: A Stakeholder \& Issues Management Approach with Cases, $5^{\text {th }}$ Edition, South-Western Cengage Learning.

Woolcock M. (2001), The place of social capital in understanding social and economic outcomes, Isuma: Canadian Journal of Policy Research, 2, 1-17

Wootton R.E., Davis O.S.P., Mottershaw A.L. Wang R.A.H., Haworth C.M.A., (2016), Exploring the Genetic Etiology of Trust in Adolescents: Combined Twin and DNA Analyses, Twin Research and Human Genetics, 19, 638-646.

Xiong A., Westlund H., Li H, Pu Y., (2017), Social Capital and Total Factor Productivity: Evidence from Chinese Provinces, China \& World Economy, 25, 22-43.

Yaldiz Hanedar E., Broccardo E., Bazzana F., (2014), Collateral requirements of SMEs: The evidence from less-developed countries, Journal of Banking and Finance, 38, 106-121. 
Table 1. Correlation coefficients of dependent variable and covariates

\begin{tabular}{|c|c|c|c|c|c|c|c|c|c|c|c|c|c|c|c|c|c|c|}
\hline & COLLATERAL & SOCIAL & ETHICS & AGE & EXPERIENCE & ISO_CERTIFY & SIZE & GDPCAP & CRINFO & FINOP & TRCREDIT & FEMALE & LCOST & INSTIT & CONC & IDV & UAI & PDI \\
\hline COLLATERAL & 1 & & & & & & & & & & & & & & & & & \\
\hline SOCIAL & $-0.148 * * * *$ & 1 & & & & & & & & & & & & & & & & \\
\hline AGE & $-0.078^{* * * *}$ & $0.174 * * *$ & $0.053^{* * * *}$ & 1 & & & & & & & & & & & & & & \\
\hline EXPERIENCE & $-0.058^{* * * *}$ & $0.086^{* * * *}$ & $0.025^{* * *}$ & $0.301^{* * *}$ & 1 & & & & & & & & & & & & & \\
\hline ISO_CERTIFY & $-0.029 * * * *$ & $-0.025 * * * *$ & $0.058^{* * * *}$ & $0.161 * * *$ & $0.0297 * * *$ & 1 & & & & & & & & & & & & \\
\hline SIZE & $0.038^{* * * *}$ & $-0.058^{* * * *}$ & $0.025^{* * * *}$ & $0.213 * * *$ & $0.085 * * *$ & $0.251 * * *$ & 1 & & & & & & & & & & & \\
\hline GDPCAP & $-0.133^{* * * *}$ & $0.423^{* * * *}$ & $0.497^{* * * *}$ & $0.104^{* * * *}$ & $0.123^{* * * *}$ & $0.093 * * *$ & $0.117^{* * * *}$ & 1 & & & & & & & & & & \\
\hline CRINFO & $-0.196 * * *$ & $0.296^{* * * *}$ & $-0.101 * * *$ & $0.165 * * *$ & $0.189^{* * * *}$ & $0.058^{* * * *}$ & $-0.191 * * *$ & $0.149^{* * *}$ & 1 & & & & & & & & & \\
\hline FINOP & $-0.074 * * *$ & $0.110^{* * * *}$ & $0.112^{* * *}$ & $0.139 * * * *$ & $0.097 * * *$ & $0.084 * * *$ & $0.165 * * *$ & $0.112^{* * *}$ & $0.129 * * *$ & 1 & & & & & & & & \\
\hline TRCREDIT & $-0.101 * * *$ & $0.139 * * *$ & $0.096 * * *$ & $0.168^{* * * *}$ & $0.141 * * *$ & $0.093 * * *$ & $0.185 * * * *$ & $0.255^{* * *}$ & $0.253 * * *$ & $0.153^{* * * *}$ & 1 & & & & & & & \\
\hline FEMALE & $0.024 * * *$ & $0.015 * *$ & $-0.043 * * *$ & $-0.065 * * *$ & $-0.093 * * * *$ & $-0.068 * * *$ & $-0.125^{* * * * *}$ & $-0.048^{* * * *}$ & -0.0082 & $-0.078^{* * * *}$ & $-0.054 * * *$ & 1 & & & & & & \\
\hline INSTIT & $-0.123^{* * * *}$ & $0.426 * * *$ & $0.629^{* * * *}$ & $0.089^{* * * *}$ & $0.086^{* * * *}$ & $0.059^{* * * *}$ & $0.067^{* * * *}$ & $0.61^{* * * *}$ & $0.109^{* * *}$ & $0.136^{* * * *}$ & $0.162^{* * * *}$ & -0.018 & $0.076^{* * * *}$ & 1 & & & & \\
\hline CONC & $0.032 * * *$ & 0.007 & $-0.045 * * *$ & -0.045 & $0.029 * * *$ & $-0.021^{* * *}$ & $-0.088 * * * *$ & $-0.099 * * * *$ & $0.138 * * *$ & -0.014 & 0.004 & -0.001 & $-0.023^{* * * *}$ & $-0.125 * * *$ & 1 & & & \\
\hline IDV & 0.013 & $0.040^{* * * *}$ & $0.097 * * *$ & $0.022 * * *$ & $0.033 * * *$ & $0.072 * * * *$ & $0.145 * * *$ & $0.58^{* * * *}$ & $-0.182 * * *$ & $0.025^{* * * *}$ & 0.0072 & $-0.041^{* * * *}$ & $0.054^{* * * *}$ & $0.551^{* * * *}$ & $-0.175^{* * * *}$ & 1 & & \\
\hline UAI & $-0.121^{* * * *}$ & $-0.054^{* * * *}$ & $-0.025 * * *$ & $0.095 * * *$ & $0.144 * * *$ & $-0.058^{* * * *}$ & $0.047 * * *$ & $-0.023^{* * * *}$ & $0.249 * * *$ & $0.109^{* * *}$ & $0.192^{* * * *}$ & $-0.023^{* * * *}$ & $0.043 * * *$ & $0.140^{* * * *}$ & $-0.189 * * * *$ & $-0.176^{* * * *}$ & 1 & \\
\hline PDI & $0.112 * * *$ & $-0.318^{* * * *}$ & $-0.222^{* * * *}$ & $-0.128^{* * * * *}$ & $-0.125^{* * * *}$ & $-0.063 * * *$ & $-0.022^{* * * *}$ & $-0.586 * * *$ & $-0.218 * * *$ & $-0.185^{* * * *}$ & $-0.155 * * *$ & $0.066^{* * * *}$ & $-0.035^{* * * *}$ & $-0.487 * * *$ & $0.156^{* * * *}$ & $-0.541 * * *$ & 0.035 & 1 \\
\hline MASC & -0.002 & $-0.108 * * *$ & $-0.453^{* * * *}$ & $-0.062^{* * * * *}$ & 0.016 & $0.044^{* * * *}$ & $0.029^{* * * *}$ & $-0.071 * * * *$ & $0.055^{* * * *}$ & $0.023^{* * * *}$ & $0.028 * * * *$ & -0.061 & -0.0098 & $-0.298 * * * *$ & $0.051^{* * *}$ & $0.061^{* * * *}$ & $-0.182^{* * * *}$ & $0.042 * * *$ \\
\hline
\end{tabular}

For the variable description, see Table A.1 in the Appendix. $* * * \mathrm{p}<0.01, * * \mathrm{p}<0.05,{ }^{*} \mathrm{p}<0.1$. 
Table 2. Descriptive statistics of variables

\begin{tabular}{lccccc}
\hline \multicolumn{1}{c}{ Variable } & Obs. & Mean & Std. Dev. & Min & Max \\
\hline COLLATERAL & 20,013 & 0.73 & 0.44 & 0 & 1 \\
COLVALUE & 12,070 & 37.78 & 63.42 & 0 & 200 \\
SOCIAL & 712 & 47.70 & 5.31 & 27 & 62 \\
ETHICS & 469 & 3.82 & 0.65 & 2.55 & 6.78 \\
AGE & 20,013 & 21.45 & 19.18 & 0 & 309 \\
EXPERIENCE & 20,013 & 20.83 & 11.55 & 0 & 70 \\
ISO_CERTIFY & 20,013 & 0.25 & 0.43 & 0 & 1 \\
MED-SIZE & 20,013 & 0.38 & 0.49 & 0 & 1 \\
LARGE-SIZE & 20,013 & 0.26 & 0.44 & 0 & 1 \\
GDPCAP & 712 & 6,126 & 7,885 & 307 & 53,562 \\
CRINFO & 712 & 2.73 & 2.69 & 0 & 8 \\
FINOP & 19,857 & 0.73 & 0.44 & 0.00 & 1.00 \\
TRCREDIT & 14,710 & 56.49 & 36.64 & 0 & 100 \\
FEMALE & 13,877 & 0.14 & 0.35 & 0 & 1 \\
LCOST & 16,656 & 0.21 & 0.18 & 0.00 & 0.87 \\
INSTIT & 702 & -0.27 & 0.71 & -1.78 & 2.06 \\
CONC & 706 & 12.14 & 8.03 & -0.24 & 53.74 \\
IDV & 423 & 33.48 & 18.65 & 6 & 80 \\
UAI & 423 & 68.21 & 19.92 & 13 & 99 \\
PDI & 423 & 46.30 & 19.75 & 5 & 100 \\
MASC & 423 & 66.94 & 17.64 & 13 & 100 \\
\hline
\end{tabular}

Notes: For the variable description, see Table A.1 in the Appendix. Descriptive statistics for the country-level variables are calculated from country-level (and not firm-level) observations to avoid double-counting. 
Table 3. Baseline results

\begin{tabular}{|c|c|c|c|c|c|c|c|c|c|c|c|c|}
\hline VARIABLES & $\begin{array}{c}(1) \\
\text { odds ratio } \\
\end{array}$ & $\begin{array}{c}(2) \\
\text { odds ratio } \\
\end{array}$ & $\begin{array}{c}(3) \\
\text { odds ratio } \\
\end{array}$ & $\begin{array}{c}\text { (4) } \\
\text { odds ratio } \\
\end{array}$ & $\begin{array}{c}(5) \\
\text { odds ratio } \\
\end{array}$ & $\begin{array}{c}(6) \\
\text { odds ratio } \\
\end{array}$ & $\begin{array}{c}(7) \\
\text { odds ratio } \\
\end{array}$ & $\begin{array}{c}(8) \\
\text { odds ratio } \\
\end{array}$ & $\begin{array}{c}(9) \\
\text { odds ratio } \\
\end{array}$ & $\begin{array}{c}(10) \\
\text { odds ratio } \\
\end{array}$ & $\begin{array}{c}(11) \\
\text { odds ratio } \\
\end{array}$ & $\begin{array}{c}(12) \\
\text { odds ratio } \\
\end{array}$ \\
\hline SOCIAL & $\begin{array}{c}0.973 * * * \\
(0.005)\end{array}$ & $\begin{array}{c}0.972 * * * \\
(0.005)\end{array}$ & $\begin{array}{c}0.980^{* * * *} \\
(0.004)\end{array}$ & $\begin{array}{c}0.988 * * * \\
(0.004)\end{array}$ & $\begin{array}{c}0.966 * * * \\
(0.006)\end{array}$ & $\begin{array}{c}0.979 * * * \\
(0.005)\end{array}$ & & & & & & \\
\hline ETHICS & & & & & & & $\begin{array}{c}0.748 * * * \\
(0.026)\end{array}$ & $\begin{array}{c}0.753 * * * \\
(0.026)\end{array}$ & $\begin{array}{c}0.800 * * * \\
(0.030)\end{array}$ & $\begin{array}{c}0.800 * * * \\
(0.030)\end{array}$ & $\begin{array}{c}0.758^{* * * *} \\
(0.029)\end{array}$ & $\begin{array}{c}0.813 * * * \\
(0.034)\end{array}$ \\
\hline AGE & $\begin{array}{c}0.998^{* *} \\
(0.001)\end{array}$ & $\begin{array}{c}0.998^{* *} \\
(0.001)\end{array}$ & $\begin{array}{c}0.997 * * * \\
(0.001)\end{array}$ & $\begin{array}{c}0.996 * * * \\
(0.001)\end{array}$ & $\begin{array}{c}0.998^{* * *} \\
(0.001)\end{array}$ & $\begin{array}{c}0.996 * * * \\
(0.001)\end{array}$ & $\begin{array}{c}0.997 * * * \\
(0.001)\end{array}$ & $\begin{array}{c}0.997 * * * \\
(0.001)\end{array}$ & $\begin{array}{l}0.997 * * \\
(0.001)\end{array}$ & $\begin{array}{c}0.997 * * \\
(0.001)\end{array}$ & $\begin{array}{c}0.996 * * * \\
(0.001)\end{array}$ & $\begin{array}{c}0.997 * * \\
(0.001)\end{array}$ \\
\hline EXPERIENCE & $\begin{array}{c}1.002 \\
(0.002)\end{array}$ & $\begin{array}{c}1.002 \\
(0.002)\end{array}$ & $\begin{array}{c}1.003 \\
(0.002)\end{array}$ & $\begin{array}{c}1.001 \\
(0.002)\end{array}$ & $\begin{array}{c}1.005 * * * \\
(0.002)\end{array}$ & $\begin{array}{c}1.006 * * * \\
(0.002)\end{array}$ & $\begin{array}{c}1.002 \\
(0.002)\end{array}$ & $\begin{array}{c}1.002 \\
(0.002)\end{array}$ & $\begin{array}{l}1.004 * \\
(0.002)\end{array}$ & $\begin{array}{c}1.002 \\
(0.002)\end{array}$ & $\begin{array}{l}1.005^{* *} \\
(0.002)\end{array}$ & $\begin{array}{c}1.007 * * * \\
(0.002)\end{array}$ \\
\hline ISO_CERTIFY & $\begin{array}{c}0.867 * * * \\
(0.036)\end{array}$ & $\begin{array}{c}0.873 * * * \\
(0.037)\end{array}$ & $\begin{array}{l}0.902 * * \\
(0.043)\end{array}$ & $\begin{array}{l}0.922 * \\
(0.045)\end{array}$ & $\begin{array}{c}0.851 * * * \\
(0.039)\end{array}$ & $\begin{array}{l}0.907^{*} \\
(0.051)\end{array}$ & $\begin{array}{c}0.884 * * * \\
(0.041)\end{array}$ & $\begin{array}{c}0.891 * * \\
(0.042)\end{array}$ & $\begin{array}{l}0.894 * * \\
(0.045)\end{array}$ & $\begin{array}{l}0.899 * * \\
(0.046)\end{array}$ & $\begin{array}{c}0.883^{* *} \\
(0.046)\end{array}$ & $\begin{array}{l}0.892 * \\
(0.052)\end{array}$ \\
\hline MED-SIZE & $\begin{array}{c}1.410^{* * * *} \\
(0.057)\end{array}$ & $\begin{array}{c}1.438^{* * *} \\
(0.059)\end{array}$ & $\begin{array}{c}1.507 * * * \\
(0.072)\end{array}$ & $\begin{array}{c}1.491 * * * \\
(0.072)\end{array}$ & $\begin{array}{c}1.418 * * * \\
(0.064)\end{array}$ & $\begin{array}{c}1.542 * * * \\
(0.087)\end{array}$ & $\begin{array}{c}1.459 * * * \\
(0.068)\end{array}$ & $\begin{array}{c}1.490 * * * \\
(0.070)\end{array}$ & $\begin{array}{c}1.555^{* * * *} \\
(0.079)\end{array}$ & $\begin{array}{c}1.580 * * * \\
(0.081)\end{array}$ & $\begin{array}{c}1.450^{* * * *} \\
(0.075)\end{array}$ & $\begin{array}{c}1.602 * * * \\
(0.096)\end{array}$ \\
\hline LARGE-SIZE & $\begin{array}{c}1.345^{* * *} \\
(0.064)\end{array}$ & $\begin{array}{c}1.392 * * * \\
(0.067)\end{array}$ & $\begin{array}{c}1.439 * * * \\
(0.079)\end{array}$ & $\begin{array}{c}1.380 * * * \\
(0.078)\end{array}$ & $\begin{array}{c}1.355^{* * *} \\
(0.071)\end{array}$ & $\begin{array}{c}1.454 * * * \\
(0.095)\end{array}$ & $\begin{array}{c}1.431 * * * \\
(0.077)\end{array}$ & $\begin{array}{c}1.481 * * * \\
(0.081)\end{array}$ & $\begin{array}{c}1.473 * * * \\
(0.087)\end{array}$ & $\begin{array}{c}1.450 * * * \\
(0.086)\end{array}$ & $\begin{array}{c}1.425 * * * \\
(0.086)\end{array}$ & $\begin{array}{c}1.478 * * * \\
(0.102)\end{array}$ \\
\hline GDPCAP & $\begin{array}{c}1.000 * * * \\
(0.000)\end{array}$ & $\begin{array}{c}1.000 * * * \\
(0.000)\end{array}$ & $\begin{array}{c}1.000 * * * \\
(0.000)\end{array}$ & $\begin{array}{c}1.000 * * * \\
(0.000)\end{array}$ & $\begin{array}{c}1.000 * * * \\
(0.000)\end{array}$ & $\begin{array}{c}1.000 * * * \\
(0.000)\end{array}$ & $\begin{array}{c}1.000 * * * \\
(0.000)\end{array}$ & $\begin{array}{c}1.000 * * * \\
0.000)\end{array}$ & $\begin{array}{c}1.000 * * * \\
(0.000)\end{array}$ & $\begin{array}{c}1.000 * * * \\
(0.000)\end{array}$ & $\begin{array}{c}1.000^{* * * *} \\
(0.000)\end{array}$ & $\begin{array}{c}1.000 * * * \\
(0.000)\end{array}$ \\
\hline CRINFO & $\begin{array}{c}0.881 * * * \\
(0.012)\end{array}$ & $\begin{array}{c}0.883^{* * *} \\
(0.012)\end{array}$ & $\begin{array}{c}0.885^{* * * *} \\
(0.010)\end{array}$ & $\begin{array}{c}0.876 * * * \\
(0.010)\end{array}$ & $\begin{array}{c}0.886 * * * \\
(0.013)\end{array}$ & $\begin{array}{c}0.894 * * * \\
(0.012)\end{array}$ & $\begin{array}{c}0.882 * * * \\
(0.013)\end{array}$ & $\begin{array}{c}0.884 * * * \\
(0.014)\end{array}$ & $\begin{array}{c}0.887 * * * \\
(0.014)\end{array}$ & $\begin{array}{c}0.881 * * * \\
(0.015)\end{array}$ & $\begin{array}{c}0.890^{* * * *} \\
(0.015)\end{array}$ & $\begin{array}{c}0.890^{* * * *} \\
(0.017)\end{array}$ \\
\hline FINOP & & $\begin{array}{c}0.822 * * * \\
(0.035)\end{array}$ & & & & $\begin{array}{c}0.809 * * * \\
(0.046)\end{array}$ & & $\begin{array}{c}0.833 * * * \\
(0.040)\end{array}$ & & & & $\begin{array}{c}0.904 \\
(0.056)\end{array}$ \\
\hline TRCREDIT & & & $\begin{array}{c}0.998 * * * \\
(0.006)\end{array}$ & & & $\begin{array}{c}0.999^{*} \\
(0.0007)\end{array}$ & & & $\begin{array}{c}0.999 \\
(0.007)\end{array}$ & & & $\begin{array}{l}1.000 \\
(0.001)\end{array}$ \\
\hline FEMALE & & & & $\begin{array}{c}1.174 * * * \\
(0.070)\end{array}$ & & $\begin{array}{l}1.157^{* *} \\
(0.080)\end{array}$ & & & & $\begin{array}{l}1.145^{* *} \\
(0.072)\end{array}$ & & $\begin{array}{l}1.128^{*} \\
(0.082)\end{array}$ \\
\hline LCOST & & & & & $\begin{array}{l}1.209 * \\
(0.131)\end{array}$ & $\begin{array}{l}1.387^{* *} \\
(0.185)\end{array}$ & & & & & $\begin{array}{c}1.187 \\
(0.146)\end{array}$ & $\begin{array}{l}1.361 * * \\
(0.195)\end{array}$ \\
\hline Constant & $\begin{array}{c}19.89^{* * * *} \\
(6.171)\end{array}$ & $\begin{array}{c}22.67 * * * \\
(7.093)\end{array}$ & $\begin{array}{c}13.26 * * * \\
(4.393)\end{array}$ & $\begin{array}{c}5.518^{* * *} \\
(1.965)\end{array}$ & $\begin{array}{c}27.48 * * * \\
(9.535)\end{array}$ & $\begin{array}{c}8.896 * * * \\
(3.619)\end{array}$ & $\begin{array}{c}19.44 * * * \\
(3.369)\end{array}$ & $\begin{array}{c}20.74 * * * \\
(3.641)\end{array}$ & $\begin{array}{c}16.21 * * * \\
(3.213)\end{array}$ & $\begin{array}{c}15.80 * * * \\
(3.756)\end{array}$ & $\begin{array}{c}16.02 * * * \\
(3.059)\end{array}$ & $\begin{array}{c}10.42 * * * \\
(2.722)\end{array}$ \\
\hline Observations & 20,013 & 19,857 & 14,710 & 13,877 & 16,656 & 10,732 & 15,194 & 15,082 & 12,984 & 12,492 & 12,547 & 9,726 \\
\hline Time Dummies & YES & YES & YES & YES & YES & YES & YES & YES & YES & YES & YES & YES \\
\hline Industry Dummies & YES & YES & YES & YES & YES & YES & YES & YES & YES & YES & YES & YES \\
\hline Regional Dummies & YES & YES & YES & YES & YES & YES & YES & YES & YES & YES & YES & YES \\
\hline Pseudo R-squared & 0.0689 & 0.0701 & 0.0630 & 0.0595 & 0.0718 & 0.0668 & 0.0719 & 0.0728 & 0.0781 & 0.0736 & 0.0736 & 0.0803 \\
\hline
\end{tabular}

Notes: Results of the Logistic Regression Model described in Equation (1) enhanced to control for: (i) the financial openness 'FINOP', (ii) trade credit 'TRCREDIT', (iii) presence of females among the owners of the firm 'FEMALE' (iv) labour cost to revenues 'LCOST'. For the variable description, see Table A.1 in the Appendix. Robust standard errors in parentheses, clustered by firm. ${ }^{* *} \mathrm{p}<0.01, * * \mathrm{p}<0.05,{ }^{*} \mathrm{p}<0.1$. Note: Odds ratios -computed as $e^{\beta}$, where $\beta$ is the coefficient of a covariate- represent the constant effect of a predictor $\mathrm{X}$, on the likelihood that an outcome (i.e. hereby pledging for collateral) will occur. 
Table 4. Controlling for bank concentration, institutional development and national culture

\begin{tabular}{|c|c|c|c|c|c|c|c|c|}
\hline VARIABLES & $\begin{array}{c}(1) \\
\text { odds ratio }\end{array}$ & $\begin{array}{c}(2) \\
\text { odds ratio }\end{array}$ & $\begin{array}{c}\text { (3) } \\
\text { odds ratio }\end{array}$ & $\begin{array}{c}\text { (4) } \\
\text { odds ratio }\end{array}$ & $\begin{array}{c}(5) \\
\text { odds ratio }\end{array}$ & $\begin{array}{c}(6) \\
\text { odds ratio }\end{array}$ & $\begin{array}{c}(7) \\
\text { odds ratio }\end{array}$ & $\begin{array}{c}\text { (8) } \\
\text { odds ratio }\end{array}$ \\
\hline SOCIAL & $\begin{array}{c}0.969 * * * \\
(0.006)\end{array}$ & $\begin{array}{c}0.985 * * \\
(0.006)\end{array}$ & $\begin{array}{c}0.943 * * * \\
(0.006)\end{array}$ & $\begin{array}{c}0.960 * * * \\
(0.007)\end{array}$ & & & & \\
\hline ETHICS & & & & & $\begin{array}{c}0.753 * * * \\
(0.026)\end{array}$ & $\begin{array}{c}0.799 * * * \\
(0.037)\end{array}$ & $\begin{array}{c}0.700 * * * \\
(0.031)\end{array}$ & $\begin{array}{c}0.830 * * \\
(0.065)\end{array}$ \\
\hline AGE & $\begin{array}{c}0.999 \\
(0.001)\end{array}$ & $\begin{array}{c}0.998 * * \\
(0.001)\end{array}$ & $\begin{array}{c}0.998 * * \\
(0.001)\end{array}$ & $\begin{array}{c}0.998 * * \\
(0.001)\end{array}$ & $\begin{array}{c}0.997 * * * \\
(0.001)\end{array}$ & $\begin{array}{c}0.996 * * * \\
(0.001)\end{array}$ & $\begin{array}{c}0.996 * * * \\
(0.001)\end{array}$ & $\begin{array}{c}0.996 * * * \\
(0.001)\end{array}$ \\
\hline EXPERIENCE & $\begin{array}{c}1.002 \\
(0.002)\end{array}$ & $\begin{array}{c}1.002 \\
(0.002)\end{array}$ & $\begin{array}{c}1.003 * * \\
(0.002)\end{array}$ & $\begin{array}{l}1.003^{*} \\
(0.002)\end{array}$ & $\begin{array}{c}1.002 \\
(0.002)\end{array}$ & $\begin{array}{c}1.002 \\
(0.002)\end{array}$ & $\begin{array}{c}1.005 * * \\
(0.002)\end{array}$ & $\begin{array}{c}1.004 * * \\
(0.002)\end{array}$ \\
\hline ISO_CERTIFY & $\begin{array}{c}0.878 * * * \\
(0.038)\end{array}$ & $\begin{array}{c}0.856 * * * \\
(0.036)\end{array}$ & $\begin{array}{c}0.879 * * * \\
(0.040)\end{array}$ & $\begin{array}{c}0.889 * * \\
(0.042)\end{array}$ & $\begin{array}{c}0.903 * * \\
(0.043)\end{array}$ & $\begin{array}{c}0.880 * * * \\
(0.041)\end{array}$ & $\begin{array}{c}0.931 \\
(0.047)\end{array}$ & $\begin{array}{c}0.946 \\
(0.049)\end{array}$ \\
\hline MED-SIZE & $\begin{array}{c}1.416^{* * * *} \\
(0.059)\end{array}$ & $\begin{array}{c}1.406 * * * \\
(0.057)\end{array}$ & $\begin{array}{c}1.451 * * * \\
(0.064)\end{array}$ & $\begin{array}{c}1.442 * * * \\
(0.066)\end{array}$ & $\begin{array}{c}1.466 * * * \\
(0.069)\end{array}$ & $\begin{array}{c}1.452 * * * \\
(0.068)\end{array}$ & $\begin{array}{c}1.449 * * * \\
(0.074)\end{array}$ & $\begin{array}{c}1.437 * * * \\
(0.075)\end{array}$ \\
\hline LARGE-SIZE & $\begin{array}{c}1.348 * * * \\
(0.066)\end{array}$ & $\begin{array}{c}1.345 * * * \\
(0.064)\end{array}$ & $\begin{array}{c}1.411 * * * \\
(0.073)\end{array}$ & $\begin{array}{c}1.395 * * * \\
(0.075)\end{array}$ & $\begin{array}{c}1.442 * * * \\
(0.080)\end{array}$ & $\begin{array}{c}1.430 * * * \\
(0.078)\end{array}$ & $\begin{array}{c}1.465 * * * \\
(0.087)\end{array}$ & $\begin{array}{c}1.454 * * * \\
(0.089)\end{array}$ \\
\hline GDPCAP & $\begin{array}{c}1.000 * * * \\
(0.000)\end{array}$ & $\begin{array}{c}1.000 * * * \\
(0.000)\end{array}$ & $\begin{array}{l}1.000 * \\
(0.000)\end{array}$ & $\begin{array}{c}1.000 \\
(0.000)\end{array}$ & $\begin{array}{c}1.000 * * * \\
(0.000)\end{array}$ & $\begin{array}{c}1.000 * * * \\
(0.000)\end{array}$ & $\begin{array}{c}1.000 * * \\
(0.000)\end{array}$ & $\begin{array}{c}1.000 \\
(0.000)\end{array}$ \\
\hline CRINFO & $\begin{array}{c}0.871 * * * \\
(0.012)\end{array}$ & $\begin{array}{c}0.891 * * * \\
(0.012)\end{array}$ & $\begin{array}{c}0.921 * * * \\
(0.017)\end{array}$ & $\begin{array}{c}0.893 * * * \\
(0.016)\end{array}$ & $\begin{array}{c}0.873 * * * \\
(0.013)\end{array}$ & $\begin{array}{c}0.882 * * * \\
(0.013)\end{array}$ & $\begin{array}{c}0.924 * * * \\
(0.020)\end{array}$ & $\begin{array}{c}0.908 * * * \\
(0.019)\end{array}$ \\
\hline CONC & $\begin{array}{c}1.030 * * * \\
(0.003)\end{array}$ & & & $\begin{array}{c}1.023^{* * *} \\
(0.003)\end{array}$ & $\begin{array}{c}1.025^{* * *} \\
(0.003)\end{array}$ & & & $\begin{array}{c}1.019 * * * \\
(0.003)\end{array}$ \\
\hline INSTIT & & $\begin{array}{c}0.690 * * * \\
(0.024)\end{array}$ & & $\begin{array}{c}0.746^{* * *} \\
(0.034)\end{array}$ & & $\begin{array}{c}0.882 * * \\
(0.053)\end{array}$ & & $\begin{array}{c}0.846 * * \\
(0.072)\end{array}$ \\
\hline INDIV & & & $\begin{array}{c}1.004 \\
(0.002)\end{array}$ & $\begin{array}{c}1.001 \\
(0.002)\end{array}$ & & & $\begin{array}{c}1.001 \\
(0.003)\end{array}$ & $\begin{array}{c}1.000 \\
(0.003)\end{array}$ \\
\hline UAI & & & $\begin{array}{c}0.984 * * * \\
(0.002)\end{array}$ & $\begin{array}{c}0.992 * * * \\
(0.002)\end{array}$ & & & $\begin{array}{c}0.980 * * * \\
(0.002)\end{array}$ & $\begin{array}{c}0.986 * * * \\
(0.002)\end{array}$ \\
\hline MASC & & & $\begin{array}{l}0.997 * \\
(0.002)\end{array}$ & $\begin{array}{c}0.995 * * * \\
(0.002)\end{array}$ & & & $\begin{array}{c}0.994 * * * \\
(0.002)\end{array}$ & $\begin{array}{l}0.996 * \\
(0.002)\end{array}$ \\
\hline PDI & & & $\begin{array}{c}1.015 * * * \\
(0.003)\end{array}$ & $\begin{array}{c}1.006^{* *} \\
(0.003)\end{array}$ & & & $\begin{array}{c}1.012 * * * \\
(0.003)\end{array}$ & $\begin{array}{l}1.006^{*} \\
(0.003)\end{array}$ \\
\hline Constant & $\begin{array}{c}0.063^{* * *} \\
(0.020)\end{array}$ & $\begin{array}{c}0.103 * * * \\
(0.033)\end{array}$ & $\begin{array}{c}0.010 * * * \\
(0.004)\end{array}$ & $\begin{array}{c}0.027 * * * \\
(0.012)\end{array}$ & $\begin{array}{c}0.0680 * * * \\
(0.012)\end{array}$ & $\begin{array}{c}0.071 * * * \\
(0.016)\end{array}$ & $\begin{array}{c}0.022 * * * \\
(0.008)\end{array}$ & $\begin{array}{c}0.054 * * * \\
(0.026)\end{array}$ \\
\hline Observations & 19,438 & 19,762 & 15,705 & 14,903 & 14,683 & 14,936 & 11,975 & 11,232 \\
\hline Time Dummies & YES & YES & YES & YES & YES & YES & YES & YES \\
\hline Industry Dummies & YES & YES & YES & YES & YES & YES & YES & YES \\
\hline Regional Dummies & YES & YES & YES & YES & YES & YES & YES & YES \\
\hline Pseudo R-squared & 0.0731 & 0.0739 & 0.0677 & 0.0714 & 0.0732 & 0.0728 & 0.0736 & 0.0731 \\
\hline
\end{tabular}

Notes: Results of the Logistic Regression Model described in Eq. (1) including: (i) Bank concentration ratio 'CONC', (ii) institutional development 'INSTIT' and (iii) national culture (INDIV, UAI, MASC, PDI). For the variable description, see Table A.1 in the Appendix. Robust standard errors in parentheses, clustered by firm. *** $\mathrm{p}<0.01$, ** $\mathrm{p}<0.05, * \mathrm{p}<0.1$. Note: Odds ratios -computed as $e^{\beta}$, where $\beta$ is the coefficient of a covariate- represent the constant effect of a predictor $\mathrm{X}$, on the likelihood that an outcome (i.e. hereby pledging for collateral) will occur. 
Table 5. Baseline model over sub-samples

\begin{tabular}{|c|c|c|c|c|c|c|c|c|c|c|}
\hline \multirow[b]{2}{*}{ VARIABLES } & \multicolumn{2}{|c|}{ Excl. GFC } & \multicolumn{2}{|c|}{ Small firms only } & \multicolumn{2}{|c|}{ Medium firms only } & \multicolumn{2}{|c|}{ Large firms only } & \multicolumn{2}{|c|}{ Private banks only } \\
\hline & $\begin{array}{c}\text { (1) } \\
\text { odds ratio }\end{array}$ & $\begin{array}{c}\text { (2) } \\
\text { odds ratio }\end{array}$ & $\begin{array}{c}\text { (3) } \\
\text { odds ratio }\end{array}$ & $\begin{array}{c}\text { (4) } \\
\text { odds ratio }\end{array}$ & $\begin{array}{c}(5) \\
\text { odds ratio }\end{array}$ & $\begin{array}{c}\text { (6) } \\
\text { odds ratio } \\
\end{array}$ & $\begin{array}{c}(7) \\
\text { odds ratio } \\
\end{array}$ & $\begin{array}{c}\text { (8) } \\
\text { odds ratio }\end{array}$ & $\begin{array}{c}\text { (9) } \\
\text { odds ratio }\end{array}$ & $\begin{array}{c}(10) \\
\text { odds ratio } \\
\end{array}$ \\
\hline SOCIAL & $\begin{array}{c}0.963 * * * \\
(0.006)\end{array}$ & & $\begin{array}{c}0.984 * * \\
(0.008)\end{array}$ & & $\begin{array}{c}0.963 * * * \\
(0.010)\end{array}$ & & $\begin{array}{c}0.967 * * * \\
(0.012)\end{array}$ & & $\begin{array}{c}0.971 * * * \\
(0.006)\end{array}$ & \\
\hline ETHICS & & $\begin{array}{c}0.752 * * * \\
(0.032)\end{array}$ & & $\begin{array}{c}0.781 * * * \\
(0.048)\end{array}$ & & $\begin{array}{c}0.795 * * * \\
(0.045)\end{array}$ & & $\begin{array}{c}0.695 * * * \\
(0.044)\end{array}$ & & $\begin{array}{c}0.752 * * * \\
(0.028)\end{array}$ \\
\hline AGE & $\begin{array}{c}0.999 \\
(0.001)\end{array}$ & $\begin{array}{c}0.997 * * * \\
(0.001)\end{array}$ & $\begin{array}{l}1.004 * \\
(0.002)\end{array}$ & $\begin{array}{c}1.000 \\
(0.003)\end{array}$ & $\begin{array}{c}1.002 \\
(0.002)\end{array}$ & $\begin{array}{c}1.003 \\
(0.002)\end{array}$ & $\begin{array}{c}0.995 * * * \\
(0.001)\end{array}$ & $\begin{array}{c}0.993 * * * \\
(0.002)\end{array}$ & $\begin{array}{c}0.998 * * \\
(0.001)\end{array}$ & $\begin{array}{c}0.996 * * * \\
(0.001)\end{array}$ \\
\hline EXPERIENCE & $\begin{array}{c}1.002 \\
(0.002)\end{array}$ & $\begin{array}{c}1.003 \\
(0.002)\end{array}$ & $\begin{array}{c}0.995 \\
(0.003)\end{array}$ & $\begin{array}{c}0.998 \\
(0.003)\end{array}$ & $\begin{array}{c}1.002 \\
(0.003)\end{array}$ & $\begin{array}{c}1.000 \\
(0.003)\end{array}$ & $\begin{array}{l}1.005 * \\
(0.003)\end{array}$ & $\begin{array}{c}1.003 \\
(0.003)\end{array}$ & $\begin{array}{c}1.002 \\
(0.002)\end{array}$ & $\begin{array}{c}1.002 \\
(0.002)\end{array}$ \\
\hline ISO_CERTIFY & $\begin{array}{c}0.868 * * * \\
(0.041)\end{array}$ & $\begin{array}{c}0.887 * * \\
(0.048)\end{array}$ & $\begin{array}{c}1.101 \\
(0.104)\end{array}$ & $\begin{array}{c}0.997 \\
(0.100)\end{array}$ & $\begin{array}{c}0.981 \\
(0.068)\end{array}$ & $\begin{array}{c}1.013 \\
(0.077)\end{array}$ & $\begin{array}{c}0.683 * * * \\
(0.047)\end{array}$ & $\begin{array}{c}0.741 * * * \\
(0.058)\end{array}$ & $\begin{array}{c}0.850 * * * \\
(0.038)\end{array}$ & $\begin{array}{c}0.867 * * * \\
(0.043)\end{array}$ \\
\hline MED-SIZE & $\begin{array}{c}1.383 * * * \\
(0.063)\end{array}$ & $\begin{array}{c}1.431 * * * \\
(0.077)\end{array}$ & & & & & & & $\begin{array}{c}1.451 * * * \\
(0.064)\end{array}$ & $\begin{array}{c}1.515 * * * \\
(0.077)\end{array}$ \\
\hline LARGE-SIZE & $\begin{array}{c}1.260 * * * \\
(0.067)\end{array}$ & $\begin{array}{c}1.348 * * * \\
(0.084)\end{array}$ & & & & & & & $\begin{array}{c}1.393 * * * \\
(0.071)\end{array}$ & $\begin{array}{c}1.485 * * * \\
(0.086)\end{array}$ \\
\hline GDPCAP & $\begin{array}{c}1.000 * * * \\
(0.000)\end{array}$ & $\begin{array}{c}1.000 * * * \\
(0.000)\end{array}$ & $\begin{array}{c}1.000 * * * \\
(0.000)\end{array}$ & $\begin{array}{c}1.000 * * * \\
(0.000)\end{array}$ & $\begin{array}{c}1.000 * * * \\
(0.000)\end{array}$ & $\begin{array}{c}1.000 * * * \\
(0.000)\end{array}$ & $\begin{array}{c}1.000^{* * * *} \\
(0.000)\end{array}$ & $\begin{array}{c}1.000 * * * \\
(0.000)\end{array}$ & $\begin{array}{c}1.000 * * * \\
(0.000)\end{array}$ & $\begin{array}{c}1.000 * * * \\
(0.000)\end{array}$ \\
\hline CRINFO & $\begin{array}{c}0.883 * * * \\
(0.014)\end{array}$ & $\begin{array}{c}0.888 * * * \\
(0.016)\end{array}$ & $\begin{array}{c}0.861 * * * \\
(0.018)\end{array}$ & $\begin{array}{c}0.871 * * * \\
(0.020)\end{array}$ & $\begin{array}{c}0.882 * * * \\
(0.019)\end{array}$ & $\begin{array}{c}0.880 * * * \\
(0.022)\end{array}$ & $\begin{array}{c}0.922 * * * \\
(0.027)\end{array}$ & $\begin{array}{c}0.908 * * * \\
(0.030)\end{array}$ & $\begin{array}{c}0.865 * * * \\
(0.013)\end{array}$ & $\begin{array}{c}0.851 * * * \\
(0.015)\end{array}$ \\
\hline Constant & $\begin{array}{c}0.028 * * * \\
(0.010)\end{array}$ & $\begin{array}{c}0.0473 * * * \\
(0.010)\end{array}$ & $\begin{array}{c}0.0605 * * * \\
(0.028)\end{array}$ & $\begin{array}{c}0.0433 * * * \\
(0.013)\end{array}$ & $\begin{array}{c}0.038 * * * \\
(0.020)\end{array}$ & $\begin{array}{c}0.070 * * * \\
(0.020)\end{array}$ & $\begin{array}{c}0.019 * * * \\
(0.013)\end{array}$ & $\begin{array}{c}0.024 * * * \\
(0.008)\end{array}$ & $\begin{array}{c}0.042 * * * \\
(0.015)\end{array}$ & $\begin{array}{c}0.044 * * * \\
(0.008)\end{array}$ \\
\hline Observations & 15,678 & 11,323 & 7,094 & 5,375 & 7,634 & 5,736 & 5,285 & 4,083 & 17,097 & 13,026 \\
\hline Time Dummies & YES & YES & YES & YES & YES & YES & YES & YES & YES & YES \\
\hline Industry Dummies & YES & YES & YES & YES & YES & YES & YES & YES & YES & YES \\
\hline Regional Dummies & YES & YES & YES & YES & YES & YES & YES & YES & YES & YES \\
\hline Pseudo R-squared & 0.0731 & 0.0773 & 0.0685 & 0.0687 & 0.0661 & 0.0664 & 0.0895 & 0.100 & 0.0780 & 0.0785 \\
\hline
\end{tabular}

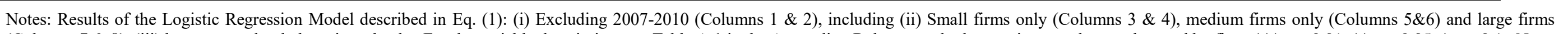

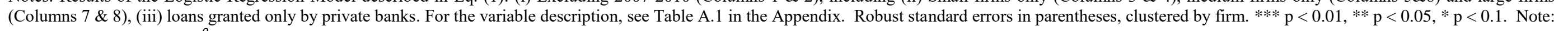
Odds ratios -computed as $e^{\beta}$, where $\beta$ is the coefficient of a covariate- represent the constant effect of a predictor X, on the likelihood that an outcome (i.e. hereby pledging for collateral) will occur. 
Table 6. Tobit Model regarding the level of collateral pledged by the firm

\begin{tabular}{|c|c|c|}
\hline VARIABLES & $\begin{array}{c}(1) \\
\text { model }\end{array}$ & $\begin{array}{c}(2) \\
\text { model }\end{array}$ \\
\hline SOCIAL & $\begin{array}{c}-13.09 * * * \\
(0.699)\end{array}$ & \\
\hline ETHICS & & $\begin{array}{c}-24.99 * * * \\
(8.144)\end{array}$ \\
\hline AGE & $\begin{array}{c}0.001 \\
(0.105)\end{array}$ & $\begin{array}{l}-0.267 \\
(0.260)\end{array}$ \\
\hline EXPERIENCE & $\begin{array}{l}0.0310 \\
(0.183)\end{array}$ & $\begin{array}{c}0.164 \\
(0.397)\end{array}$ \\
\hline ISO_CERTIFY & $\begin{array}{c}-23.94 * * * \\
(4.912)\end{array}$ & $\begin{array}{l}-15.27 \\
(11.57)\end{array}$ \\
\hline GDPCAP & $\begin{array}{l}-0.001 \\
(0.001)\end{array}$ & $\begin{array}{c}-0.006 * * * \\
(0.002)\end{array}$ \\
\hline CRINFO & $\begin{array}{c}1.039 \\
(1.166)\end{array}$ & $\begin{array}{l}-8.799 \\
(6.554)\end{array}$ \\
\hline MED-SIZE & $\begin{array}{l}10.80 * \\
(5.726)\end{array}$ & $\begin{array}{c}3.314 \\
(10.29)\end{array}$ \\
\hline LARGE-SIZE & $\begin{array}{l}10.65^{*} \\
(5.740)\end{array}$ & $\begin{array}{c}8.797 \\
(12.75)\end{array}$ \\
\hline Constant & $\begin{array}{c}730.9^{* * *} \\
(30.93)\end{array}$ & $\begin{array}{c}120.5^{* * *} \\
(39.48)\end{array}$ \\
\hline Observations & 12,070 & 7,084 \\
\hline Time Dummies & YES & YES \\
\hline Industry Dummies & YES & YES \\
\hline Regional Dummies & YES & YES \\
\hline R-squared & 0.105 & 0.193 \\
\hline
\end{tabular}

Notes: Results of the Tobit model (left censored at 0 ). Firms not pledging collateral receive a value of ' 0 '. For the variable description, see Table A.1 in the Appendix. Robust standard errors in parentheses, clustered by firm. $* * * p<0.01, * * \mathrm{p}<0.05$, $* \mathrm{p}<0.1$ (i.e. hereby pledging for collateral) will occur. 
Table 7. Alleviating Endogeneity: Two-Stage Residual Inclusion (2SRI)

\begin{tabular}{|c|c|c|}
\hline & (1) & (2) \\
\hline VARIABLES & odds ratio & odds ratio \\
\hline SOCIAL & $\begin{array}{c}0.907 * * * \\
(0.027)\end{array}$ & \\
\hline$\varepsilon_{\text {SOCIAL }}$ & $\begin{array}{l}1.078^{* *} \\
(0.034)\end{array}$ & \\
\hline ETHICS & & $\begin{array}{c}0.584 * * * \\
(0.065)\end{array}$ \\
\hline$\varepsilon_{\text {ETHICS }}$ & & $\begin{array}{c}1.363^{* * *} \\
(0.163)\end{array}$ \\
\hline AGE & $\begin{array}{c}0.999 \\
(0.001)\end{array}$ & $\begin{array}{c}0.997 * * * \\
(0.001)\end{array}$ \\
\hline EXPERIENCE & $\begin{array}{c}1.002 \\
(0.002)\end{array}$ & $\begin{array}{c}1.002 \\
(0.002)\end{array}$ \\
\hline ISO_CERTIFY & $\begin{array}{c}0.866 * * * \\
(0.037)\end{array}$ & $\begin{array}{c}0.886^{* *} \\
(0.043)\end{array}$ \\
\hline MED-SIZE & $\begin{array}{c}1.416 * * * \\
(0.060)\end{array}$ & $\begin{array}{c}1.485 * * * \\
(0.071)\end{array}$ \\
\hline LARGE-SIZE & $\begin{array}{c}1.332 * * * \\
(0.066)\end{array}$ & $\begin{array}{c}1.439 * * * \\
(0.080)\end{array}$ \\
\hline GDPCAP & $\begin{array}{c}1.000 \\
(0.000)\end{array}$ & $\begin{array}{c}1.000 * * \\
(0.000)\end{array}$ \\
\hline CRINFO & $\begin{array}{c}0.867 * * * \\
(0.016)\end{array}$ & $\begin{array}{c}0.908 * * * \\
(0.015)\end{array}$ \\
\hline Constant & $\begin{array}{c}0.002 * * * \\
(0.003)\end{array}$ & $\begin{array}{c}0.020 * * * \\
(0.009)\end{array}$ \\
\hline Observations & 18,979 & 14,275 \\
\hline Time Dummies & YES & YES \\
\hline Industry Dummies & YES & YES \\
\hline Regional Dummies & YES & YES \\
\hline R-squared & 0.0713 & 0.0788 \\
\hline \multicolumn{3}{|l|}{ First Stage Output: } \\
\hline Agricultural potential & $\begin{array}{c}0.0001 * * * \\
(0.000)\end{array}$ & $\begin{array}{c}0.0002 * * * \\
(0.000)\end{array}$ \\
\hline Genetic Diversity & $\begin{array}{c}15.200 * * * \\
(1.046)\end{array}$ & $\begin{array}{c}2.046 * * * \\
(0.087)\end{array}$ \\
\hline Latitude & $\begin{array}{l}-0.165^{* * *} \\
(0.00191)\end{array}$ & $\begin{array}{l}-0.012 * * * \\
(0.000194)\end{array}$ \\
\hline Other exogenous & YES & YES \\
\hline R-squared & 0.5459 & 0.4868 \\
\hline Prob $>$ F & 0.000 & 0.000 \\
\hline
\end{tabular}

Notes: Results of the 2SRI model. First stage instruments are the predicted genetic diversity (ancestry adjusted), absolute value of the latitudinal distance from equator and agricultural potential (see section 4.3 for a detailed discussion). For the variable description, see Table A.1 in the Appendix. Robust standard errors in parentheses, clustered by firm. $* * * \mathrm{p}<0.01, * * \mathrm{p}<0.05, * \mathrm{p}<0.1$ (i.e. hereby pledging for collateral) will occur. 
Table A.1. Variable Description

\begin{tabular}{|c|c|c|}
\hline Variable & Description & Source \\
\hline COLLATERAL & A variable that takes ' 1 ' if a firm pledged collateral and ' 0 ' otherwise. & WBES \\
\hline COLVALUE & Value of collateral asked to be pledged as $\%$ of the loan value. & WBES \\
\hline SOCIAL & $\begin{array}{l}\text { Reflects the strength of personal and social relationships, social } \\
\text { norms and civic participation in a country. }\end{array}$ & Legatum Institute \\
\hline ETHICS & $\begin{array}{l}\text { Denotes the WEF's survey on leaders' views on how ethical } \\
\text { corporations behave in a country and takes values from } 1 \text { to } 7 \text {, with } \\
\text { higher figures indicating higher ethical behavior and vice versa. }\end{array}$ & World Economic Forum \\
\hline AGE & Number of years a firm is in operation. & WBES \\
\hline EXPERIENCE & $\begin{array}{l}\text { Shows the years of sector experience the manager of a firm boasts in } \\
\text { one's resumé. }\end{array}$ & WBES \\
\hline ISO_CERTIFY & $\begin{array}{l}\text { Dummy variable on whether a firm has internationally-recognized } \\
\text { quality certification (e.g. ISO 9000, ISO 9002). }\end{array}$ & WBES \\
\hline MED-SIZE & $\begin{array}{l}\text { Dummy variable that takes the value of ' } 1 \text { ' whether a firm is a } \\
\text { medium -sized firm and ' } 0 \text { ' otherwise. }\end{array}$ & WBES \\
\hline LARGE-SIZE & $\begin{array}{l}\text { Dummy variable that takes the value of ' } 1 \text { ' whether a firm is a large } \\
\text {-sized firm and ' } 0 \text { ' otherwise. }\end{array}$ & WBES \\
\hline FEMALE & $\begin{array}{l}\text { Reflects whether there are any females amongst the owners of the } \\
\text { firm. }\end{array}$ & WBES \\
\hline FINOP & $\begin{array}{l}\text { This variable may take the value of zero in the case of firms with no } \\
\text { checking/savings account or overdraft, the value of one in the case } \\
\text { of firms that have either checking/savings account or overdraft, and } \\
\text { the value of two in the case where a firm has both checking/savings } \\
\text { account and an overdraft facility. }\end{array}$ & WBES \\
\hline LCOST & The ratio of labour cost to revenues. & WBES \\
\hline TRCREDIT & $\begin{array}{l}\text { Using the percentage of the material inputs or services that were } \\
\text { paid after delivery. }\end{array}$ & WBES \\
\hline GDPCAP & $\begin{array}{l}\text { Per capita gross domestic product based on purchasing power parity } \\
\text { (PPP). }\end{array}$ & World Development Indicators \\
\hline CRINFO & $\begin{array}{l}\text { Index where higher values indicate the availability of more credit } \\
\text { information, from either a public registry or a private bureau, to } \\
\text { facilitate lending decisions. }\end{array}$ & Doing Business Project \\
\hline CONC & $\begin{array}{l}\text { proportion of assets held by the three largest commercial banks in a } \\
\text { country. Higher figures indicate that only a few banks dominate in } \\
\text { the market, and hence there is a lower degree of competition. }\end{array}$ & Global Financial Development \\
\hline INSTIT & $\begin{array}{l}\text { Index calculated as the average of the following three indicators: } \\
\text { regulatory quality, rule of law, control of corruption. Higher figures } \\
\text { denote better outcomes. }\end{array}$ & World Governance Indicators \\
\hline UAI & Uncertainty Avoidance index. & Hofstede Insights \\
\hline
\end{tabular}




\begin{tabular}{|l|l|c|}
\hline PDI & Power Distance index. & Hofstede Insights \\
\hline IDV & Individualism index. & Hofstede Insights \\
\hline MASC & Masculinity index. & Hofstede Insights \\
\hline Agricultural potential & $\begin{array}{l}\text { Mean potential caloric yield attainable given the set of crops that } \\
\text { were suitable for cultivation in the post-1500 period. }\end{array}$ & \\
\hline Genetic diversity & $\begin{array}{l}\text { Ancestry adjusted predicted genetic diversity, estimated on the basis } \\
\text { of migratory distance from East Africa. }\end{array}$ & Ashraf and Galor (2013) \\
\hline Latitude & The absolute value of the latitudinal distance from equator. & Ashraf and Galor (2013) \\
\hline
\end{tabular}

